$1-1-1953$

\title{
Development of vegetation on century-old iron-ore spoil banks
}

\author{
Earl H. Tryon
}

R. Nudolfs Markus

Follow this and additional works at: https://researchrepository.wvu.edu/ wv_agricultural_and_forestry_experiment_station_bulletins

\section{Digital Commons Citation}

Tryon, Earl H. and Markus, R. Nudolfs, "Development of vegetation on century-old iron-ore spoil banks" (1953). West Virginia Agricultural and Forestry Experiment Station Bulletins. 360.

https://researchrepository.wvu.edu/wv_agricultural_and_forestry_experiment_station_bulletins/358 @ WVU. It has been accepted for inclusion in West Virginia Agricultural and Forestry Experiment Station Bulletins by an authorized administrator of The Research Repository @ WVU. For more information, please contact ian.harmon@mail.wvu.edu. 
(1)


(1)



in

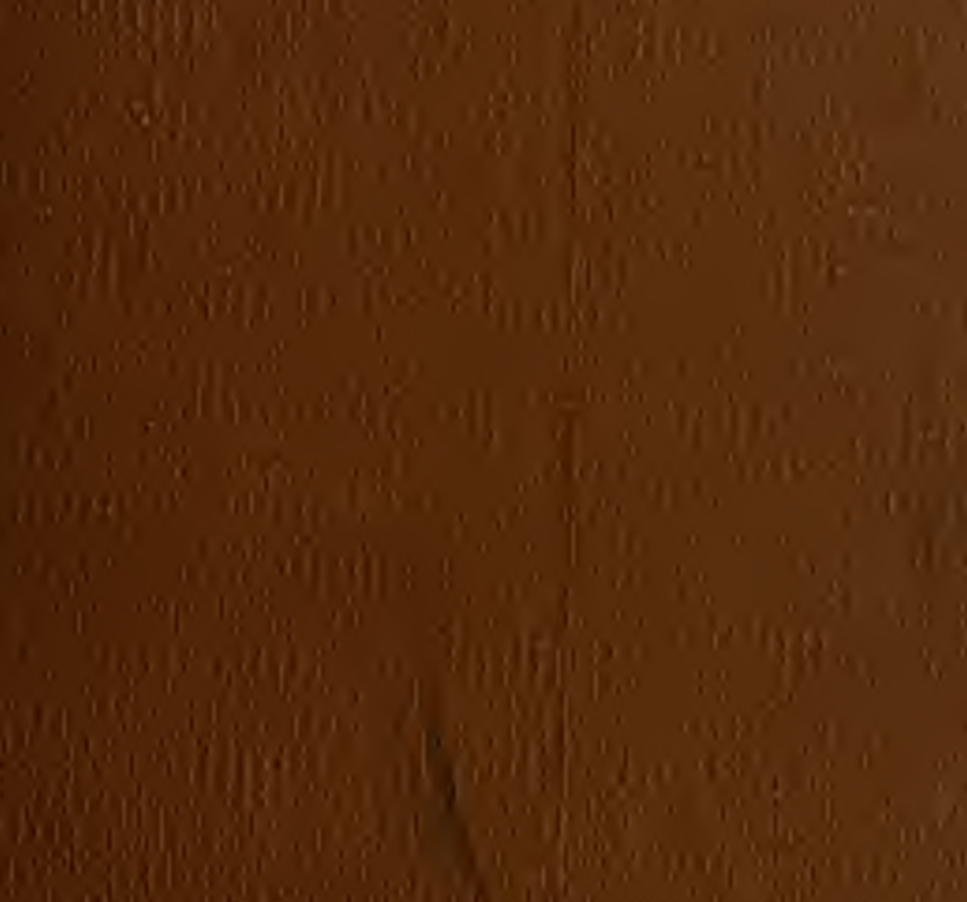

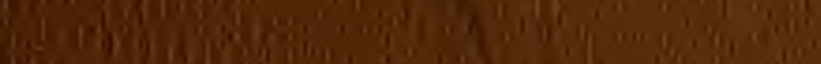

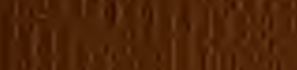
\begin{tabular}{l}
0.9 \\
\hline
\end{tabular} So:

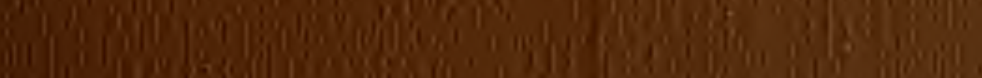


|lis 1) (10: a 



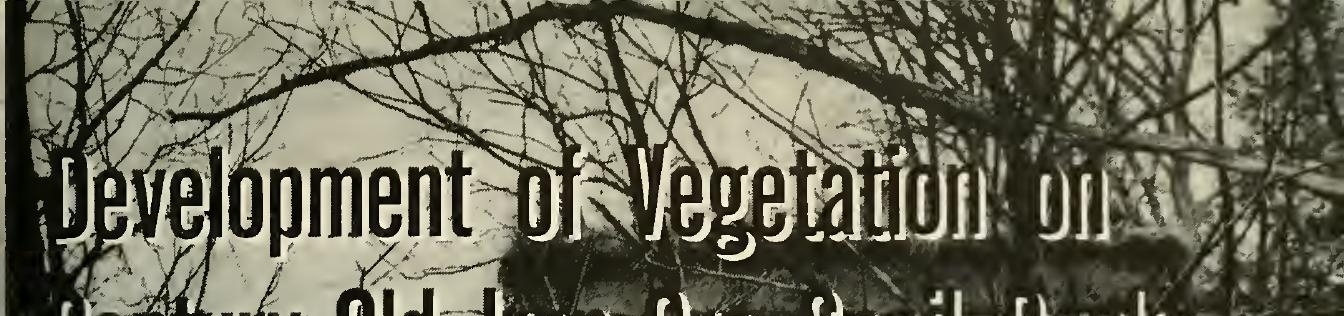

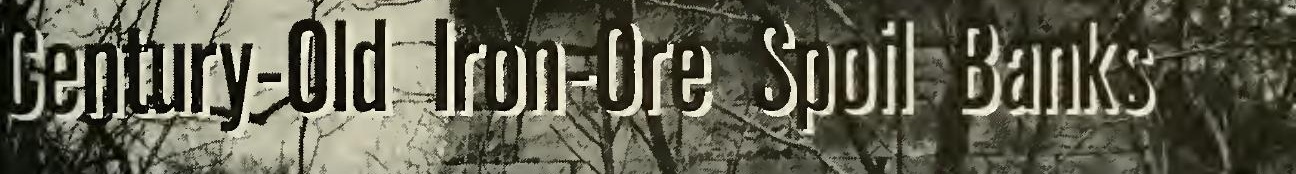

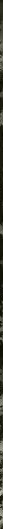
Bullat 360 -

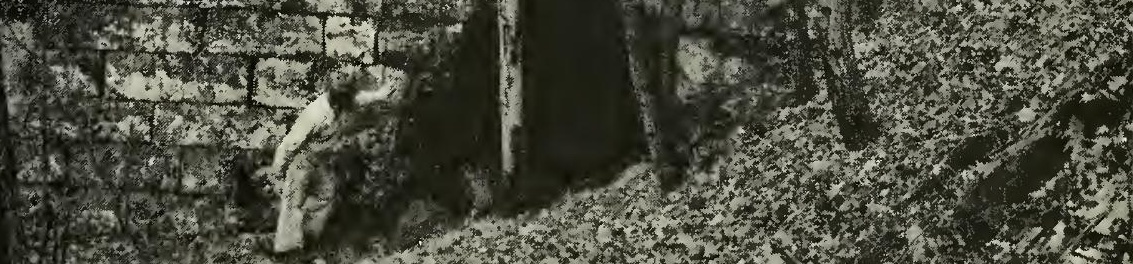





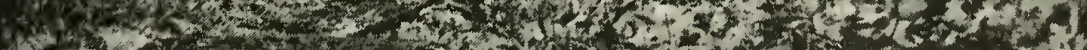

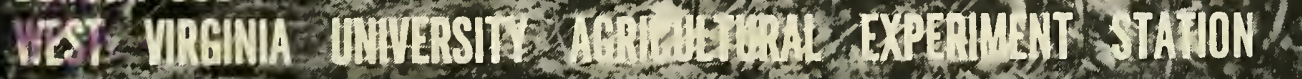




\section{THE AUTHORS}

E. H. Tryon is Silviculturist at the West Virginia University Agricultural Experiment Station and Professor of Silviculture in the College of Agriculture, Forestry, and Home Economics.

Rudolfs Markus is a Forest Engineer and was Visiting Research Professor of Forestry at West Virginia University in 1949.

\section{THE COVER}

Pictured on the cover is the Virginia Furnace, built in 1852-3 by Harrison Hagens for the production of "charcoal iron." (So-called because charcoal was used as fuel in the smelting of the iron ore.)

This furnace is located on Muddy Creek near Albright. In 1879 it operated under the name of Josephine Furnace, and ceased operations in 1880.

West Virginia UNIVERSITY

Agrigultural Experiment Station

College of Agriculture, Forestri; and Hone Economics

A. H. Vanlandinghan, Agting Director 
Development of Vegetation on Century-Old Iron-Ore Spoil Banks

\author{
by \\ E. H. Tryon and \\ Rudolfs Markus
}

WEST VIRGINIA UNIVERSITY AGRICULTURAL EXPERIMENT STATION 


\section{ACKNOWLEDGMENTS}

Many persons assisted in gathering information for this bulletin. Dr. E. H. Tyner, formerly Agronomist with the West Virginia University Agricultural Experiment Station, contributed substantially when the work was first organized. Dr. Earl L. Core and Miss Elizabeth A. Bartholomew of the Department of Biology gave valuable assistance in the identification of plants. Dr. Siclney L. Galpin, Hydrologist, and Dr. G. Gordon Pohlman, Agronomist, of the Department of Agronomy and Genetics, aided in many ways when the field work was in progress and during the preparation of the manuscript. George McVicker, George Ruth, and Robert King, formerly students of the Division of Forestry, and Gordon Roy, a student in the Division of Forestry, aided in the field work.

Mr. Arden Peters and Mr. Glen Massey, residents of Gladesville, permitted the study of iron-ore spoil banks on their lands. Mr. Thayer Holmes, Mr. H. J. Linton, and Mr. J. C. Jackson, some of the older residents of Gladesville, gave much information on the history of the iron-ore industry and assisted in locating spoil banks.

To all these people, the authors express their thanks. 


\section{CONTENTS}

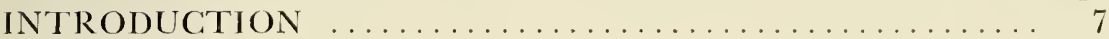

DESCRIPTION AND HISTORY OF AREAS ........... 9

CoOpers Rock Area ...................... 10

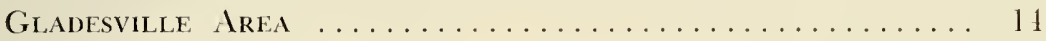

DESCRIPTION OF UNITS .................... 16

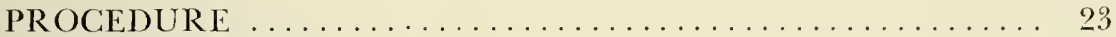

Forested UnITS .......................... 23

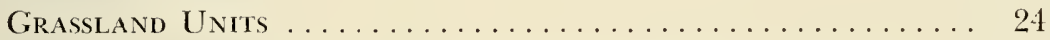

RESULTS OF INVESTIGATION ON FORESTED UNITS .... 25

Comparison of Composition of Vegetation on Spolls with

Adjacent Controls ........................ 25

Abundance of Wood Vegetation 0.6 Inches in Diameter and Above ............................. 25

Abundance of Reproduction ................... 27

Abundance of Ground Cover ................... 29

Comparison of Site Quality of Spolls with Adjacent

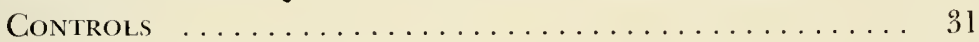

Site Index Determination ................ 31

Growth of Individual Large Trees $\ldots \ldots \ldots \ldots \ldots \ldots \ldots .36$

Radial Growth on Old Stumps ................ 38

Root Distribution ..................... 43

RESULTS OF INVESTIGATION ON GRASSLAND UNITS ... 48

Comparison of Species Abundance on Spolls with Adjacent

Controls ............................. 48

Comparison of Forage Production on Spolls with adjacent Controls ............................. 52

CONCLUSIONS ............................ 54

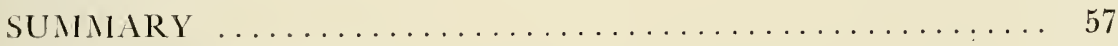

LITERATURE CITED ....................... 59

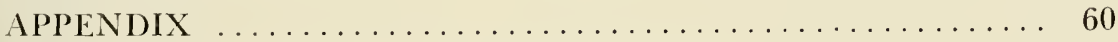

Common and Technical Names of Trees $\ldots \ldots \ldots \ldots \ldots \ldots .60$

Common and Teghnical Names of Herbs and Shrubs ...... 61

Common and Technical Names of Fungi . . . . . . . . . 63 
Digitized by the Internet Archive in 2010 with funding from

Lyrasis Members and Sloan Foundation 


\section{Development of Vegetation on Century-Old Iron-Ore Spoil Banks}

E. H. TRYON AND RUDOLFS MARKUS

\section{INTRODUCTION}

Strip coal mining on a sizable scale is relatively recent. In West Virginia most of the stripping has taken place since 1940 (20). In the United States, approximately 225,000 acres had been stripped for coal by 1947 (4), and in West Virginia about 40,000 acres have now been affected by these operations. Stripping consists of uncovering coal seams and piling the soil and rocky over-burden to one side and then removing the coal. This results in unsightly spoil banks composed of broken up materials such as sandstones, shales, limestones, and clays, or combinations of these. Immediately after being formed the spoils are low in nitrogen and bare of vegetation.

Most of these spoils are able to support vegetation immediately after their formation, although large areas of such spoils may remain bare or support only weeds unless sowed or planted. A small percentage of the spoil banks, because of pyritic materials, are extremely acid. Such banks will not be capable of supporting vegetation for several years. Fortumately, the acreage of these acid spoils is limited, being less than 10 per cent of the total spoil area in West Virginia.

In 1945 the West Virginia Legislature specified that the strip mine operator was responsible for revegetating the spoil area (1). Under this act the surface owner has his choice of trees, shrubs, grasses, or vines, but the species used are to be prescribed by the State Department of Mines and the West Virginia University Agricultural Experiment Station. Therefore, species that will grow satisfactorily when planted or seeded on these spoil banks must be known.

In 1943 the Agricultural Experiment Station of West Virginia University began investigations concerning the revegetation of strip-mine spoil banks. The spoil banks in the State were classified into three types, the main basis of classification being the degree of acidity (19). Seeding of forage crops on the different types of spoil was started in 1943, and in 1945 reforestation work began. 
Recommendations can now be made for the selection of suitable forage crops to be used in revegetating the spoil banks.

Much knowledge concerning the survival and early growth of tree species established on spoil banks has been accumulated during the last lew years. The United States Forest Service, state experiment stations, and private companies have contributed information. With such information available, it is possible to choose tree species which can be expected to grow satisfactorily during their youth on the majority of spoils.

However, trees existing on spoil banks formed from coal stripping whether planted or resulting from natural seeding, are young. Few stands are more than fifteen years old, although spoil banks have been reported in West Virginia (14) and in Missouri (16) as supporting naturally established hardwood stands as old as thirty years. These have grown satisfactorily. In West Virginia, plantations are less than fifteen years old.

On these young spoil banks, the trees that have become established naturally, as well as those planted, are too young to determine with certainty the growth rate beyond the first few years. There is no way to know il they will grow satisfactorily to maturity and produce a merchantable crop. Certainly there is the possibility that tree growth, which often is adequate on the spoils during the first ten or fifteen years, may slow down substantially during the following two or three decades. At such time, competition will be increased and each tree will make greater demands on the spoil for moisture and nutrients. Not only is the spoil material an unnatural medium for root growth from the standpoint of texture, but nitrogen is extremely low since the topsoil is buried during the stripping operation.

The ability of an area to produce timber-the site quality-is commonly determined by foresters using tree heights at a specified age, with the taller trees indicating a better site quality. However, this method cannot be used with a high degree of accuracy on young stands of timber. Rapid height growth during the juvenile stage may or may not indicate a relatively fast growth rate as the stand matures. Baker (2, p. 32l) mentioned that forest stands on thin soils over hardpans will grow well in height during their youth, but poorly as they approach maturity. Coile (5, p. 11) working with pines in North Carolina pointed out that site quality could not be determined from very young stands.

Plantations have been observed in which growth is rapid at first and then slows down considerably more than would be predicted from the early growth rate. Plantations of four coniferous species were established in prairie soils in Illinois (9), and all four grew rapidly in height for twenty-five to thirty years, indicating a high site quality. 
Following this period, however, height growth became relatively slower until an age of seventy years was reached, at which time the height indicated a poor site quality.

Thus, even on normal soils the future growth of young forest stands cannot be predicted with certainty; and on the spoil-an unnatural growth medium-the future growth may be even more difficult to predict.

During the revegetation work on the coal-stripped spoil banks, considerable thought has been given to the future growth of the species established on them. Because only the early development of vegetation on the young coal spoils could be determined, it was decided to study the growth of the older trees and herbaceous plants, as well as soil development, ${ }^{1}$ on iron-ore spoil banks that exist in northern West Virginia. These spoil banks were formed in much the same way as the coal spoils; but are much older. Those studied were formed between 72 and 131 years ago.

The formation of the spoil banks resulting from stripping for iron ore is essentially the same as in stripping for coal. Both types of banks are much alike, although certain differences do exist. Usually the coal spoils are larger in area and deeper. Several years were required to form iron-ore spoil, as mechanized equipment was not then available, whereas a coal spoil may be formed in a few months. A coal spoil is more variable in texture and $\mathrm{pH}$, and higher in sulphur, although lime in the overburden may give a bank a $\mathrm{pH}$ of 7.0 or even higher. The coal spoils, particularly those leveled, are probably more compact because of the heavy equipment used in the operation.

In spite of these differences it is believed that the coal and iron-ore spoils are enough alike that the condition of the vegetation found on the older iron-ore spoils will indicate what may be expected on many of the newer coal spoils.

The purpose of this bulletin is to show comparisons of the composition and growth of vegetation on old iron-ore spoil banks with adjacent undisturbed areas. It is particularly hoped that the study will shed light on the ability of a forest stand to develop toward maturity on these old spoils, and will indicate, in a general way, how vegetation may be expected to develop on the present-day spoil banks formed by coal stripping.

\section{DESCRIPTION AND HISTORY OF AREAS}

The iron-ore spoil banks studied are located in two areas approximately twenty miles apart in northern West Virginia. One is known as

1A study of the rate of soil development of the iron-ore spoil banks is currently underway. 
the Coopers Rock Area and the other as the Gladesville Area. Their location is shown in Figure 1.

\section{Coopers Rock Area}

The Coopers Rock Area, located in Coopers Rock State Forest, is in northeastern Monongalia County approximately ten miles northeast of Morgantown. It lies at an elevation between 1,900 and 2,300 feet near the axis of the Chestnut Ridge anticline. The terrain, like that of the locality in general, is rugged and mountainous.

The area is favored with moderately high precipitation evenly distributed throughout the year. The nearest weather station, Bruceton Mills, located eight miles to the east and 500 feet lower in elevation, has a normal annual rainfall of 52 inches; and Morgantown, ten miles southwest of the area and 1,000 feet lower in elevation, has a normal annual rainfall of 41 inches $(21$, p. 1182). The prevailing southwest winds are

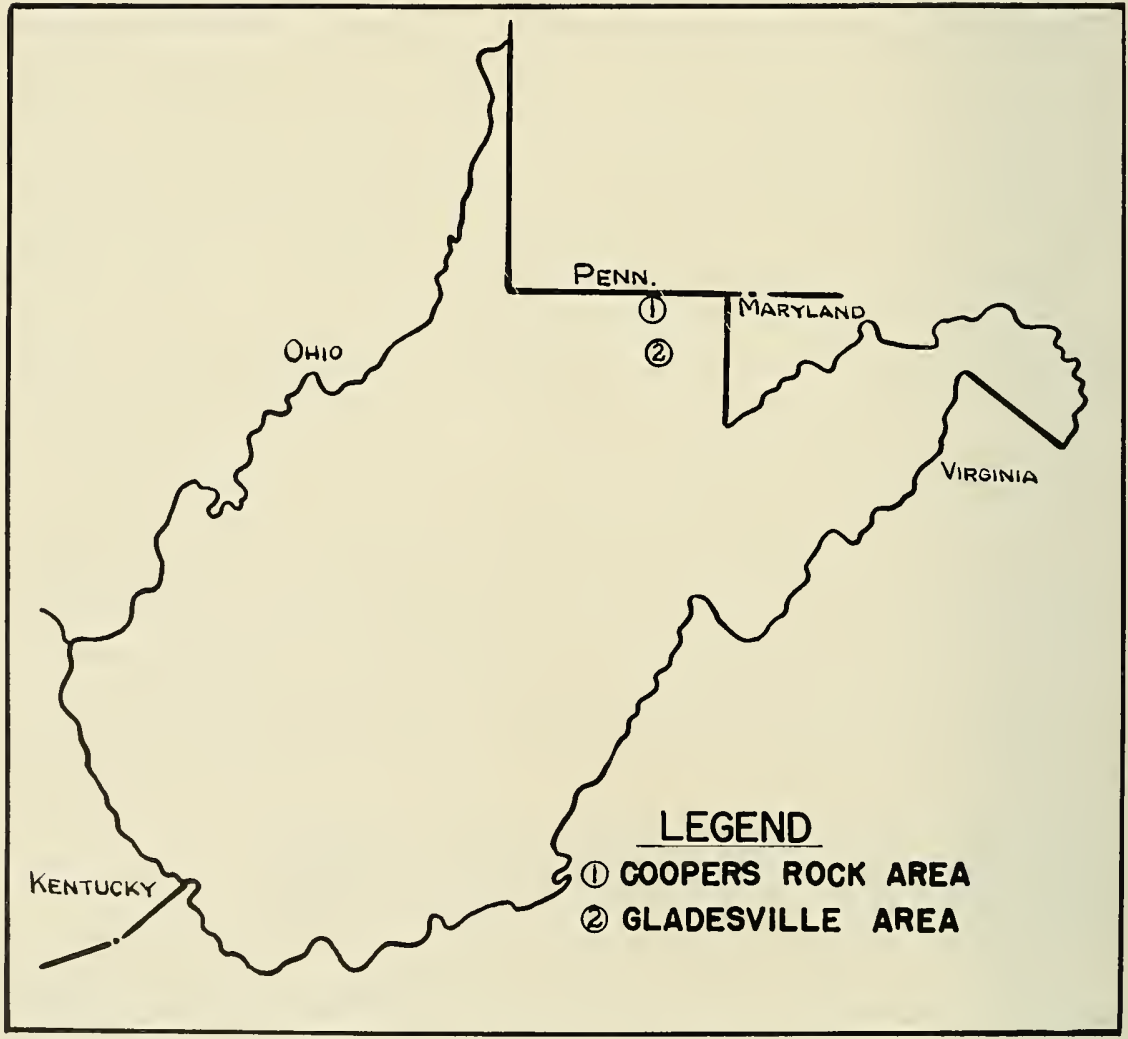

FIGURE 1. LOCATION of Coopers Rock and Gladesville Areas in West Virginia. 
elevated and cooled as they approach the area from the direction of Morgantown, and precipitation is increased. The anount of precipitation received at the area has not been measured, but observations indicate that it may approach or equal the 52 inches received at Bruceton Mills.

A mild climate and a 140-day growing season, combined with a favorable, evenly distributed annual precipitation, are important factors in producing the tree growth which is good over much of the area. Except on the dry ridges, the area may be considered a good site for hardwood timber production.

The soils belong to the Gray-Brown Podzolic Soil Group. On the hillsides they are quite shallow and acid, being derived mainly from acid sandstones and shales. The soil surface has a heavy accumulation of large sandstones and boulders. In places soil samples may be obtained only with considerable difficulty because of the great abundance of these stones. The humus is a mull and thin.

This area lies in the Pottsville series of the Carboniferous system. The spoil banks are mainly composed of shales that overlaid the iron ore. Sandstones are present only in small amounts in the spoil banks. The formation of the iron ore indicates that either limestone or a calcareous shale was present where the iron was precipitated. The shales are dark and made up of relatively coarse materials, being silty or even sandy.

The original, uncut forest of the Coopers Rock Area and surrounding territory appears to have contained high percentages of chestnut ${ }^{2}$ and species of oak. Today, evidence of many other species in the original forest may be found, but their relative abundance at that time cannot be determined. Some of these species are black cherry, black locust, black walnut, cucumbertree, red maple, sugar maple, yellowpoplar, and hickories. Eastem hemlock grew along the streams and pitch pine grew on dry ridges. The forests of this area are classified as belonging to the oak-chestnut community of the Mixed Mesophytic Forest region $(3$, p. 81).

Many stumps, stringers used in bridge construction, and railroad ties of chestnut can be found on dry portions of old logging roads. Also, fragments of charcoal used in the smelting of iron ore have been found in the slag near the old furnaces. Many of the fragments are still identifiable, and all observed and identified have been either chestnut or oak, inclicating the use of large amounts of these woods in the industry. Fragments of chestnut and oak charcoal are shown imbedded in slag in Figure 2. 


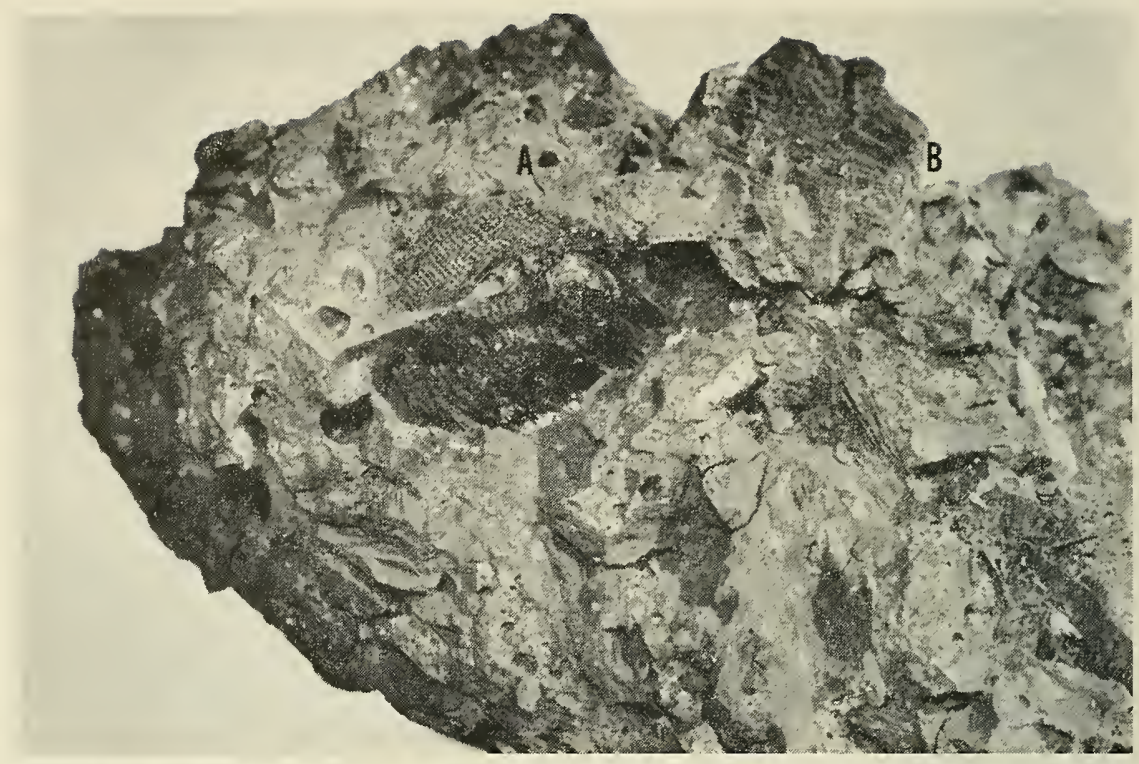

FIGURE 2. SLAG with imbedded charcoal. Found near a furnace that ran from 1799 to 1811. (A) chestnut, (B) oak.

The original forest, with its abundance of chestnut and oaks, was little affected by man until shortly before 1800 . Then iron ore was mined and iron produced in furnaces. The first furnace to be constructed in the area was the Pleasant Furnace (Figure 3). Moreland (11, p. 60) reported that this furnace was either built or enlarged about 1799 . It ceased operations in 1811.

The major production period for iron, and consequently the time of greatest cutting of timber for charcoal, was between 1822 and 1866 . During this period three furnaces, the Woodgrove, Henry Clay, and Anna, were smelting ore mined in the Coopers Rock Area. Grimsley (7, p. 11) clescribes these three furnaces.

A consiclerable amount of timber, converted to charcoal, was required for smelting the ore in the production of pig iron. It is estimated that wood lrom 10,000) acres was required to supply the charcoal needed to run the three furnaces during the forty-four-year period they were in operation. This is based on the assumption that the original forest contained fifty cords of wood per acre. This figure is a rough estimate, but it does indicate that heavy cutting occurred.

Moreland (11, p. 50) quoted a report from a newspaper article in which a resident of the area, then a boy, observed that around 1855 or 1860 "the timber on the mountain sicles was all cut and burned for 


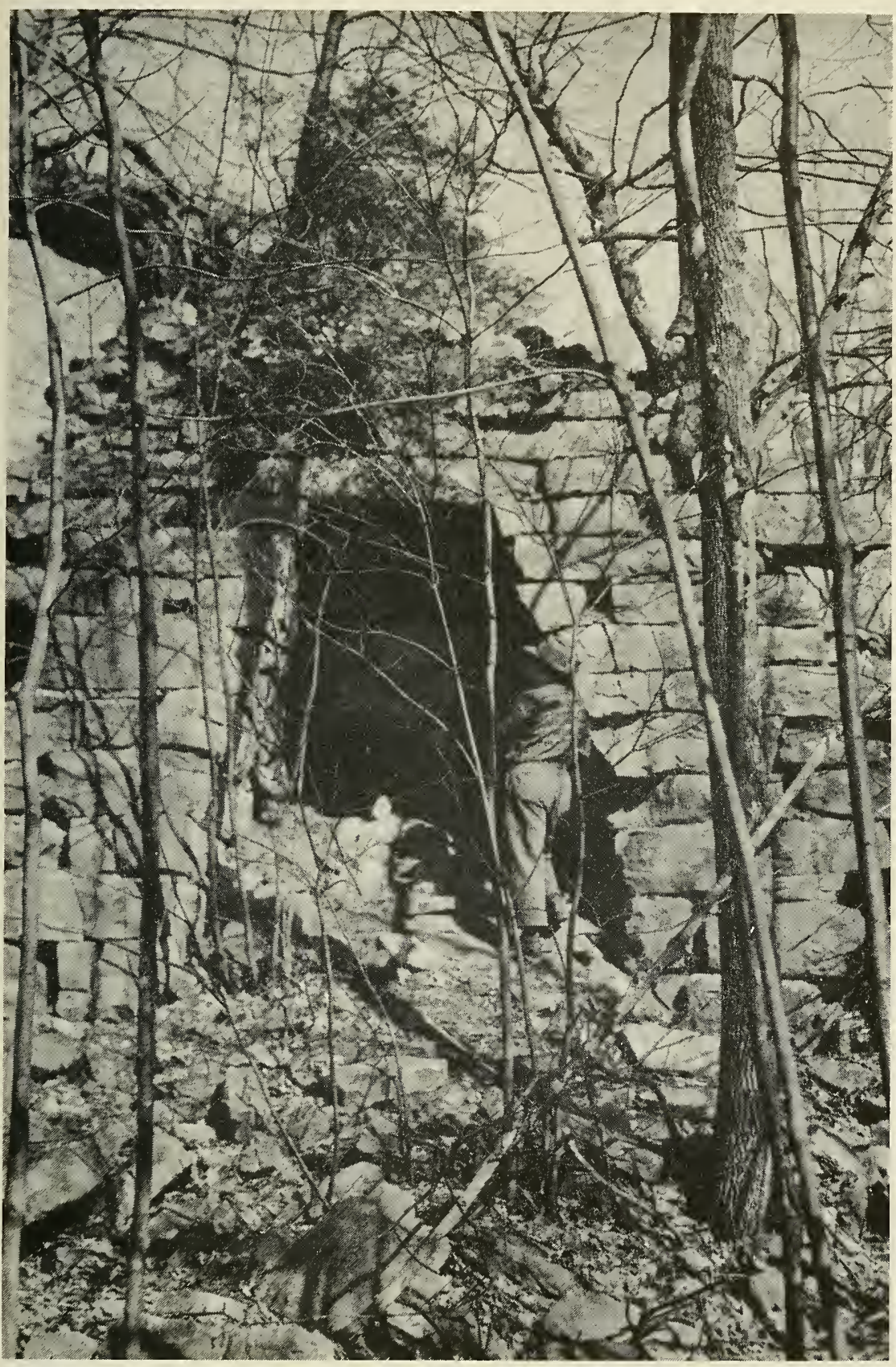

FIGURE 3. REMAINS of Pleasant Furnace built about 1799; ceased operation 1811. 
charcoal ... Sometimes there would be 40 or 50 charcoal piles burning in one evening." Undoubtedly the timber on all the land in the vicinity and including the study area was cut for charcoal.

The chestnut blight attacked the chestnut trees about 1921 or 1922, and today no large chestnut trees are on the area, but they are still sprouting over most of the forest.

Following this cutting, the forest apparently recovered rapidly because, beginning in the early 1900's it was logged. The Coopers Rock Area was logged in 1924 and 1925 by the Kendall Lumber Company.3 All of the timber was removed. Burns were frequent until 1936 when the State became the owner of the Coopers Rock State Forest. Since then fires have been almost unknown.

The present stands of timber on the study area are young, less than thirty years old, and largely of sprout origin. Species of oak predominate on many hillsides and ridges. Yellowpoplar is common in coves and on north slopes. The species present today are much the same as those in the original forest. However, chestnut occurs only as young sprouts. These are soon killed by the blight.

\section{Gladesville Area}

The Gladesville Area is located near the western boundary of Preston County, twelve miles southeast of Morgantown and ten miles west of Kingwood, and has an elevation of 1,800 to 1,900 feet. The terrain is composed of rolling hills containing much good agricultural land. The precipitation is moderately high and well distributed throughout the year. The closest weather stations are Grafton, Morgantown, and Terra Alta. Grafton, located 11 miles to the southwest at an elevation of 1,000 feet has a normal annual precipitation of 46 inches, five more than Morgantown. Terra Alta, 18 miles east at an elevation of 2,600 feet has a normal annual precipitation of 54 inches. Presumably the precipitation of the Gladesville Area will approach an average of 50 inches a year. In general the climatic factors of site are similar to those of the Coopers Rock Area, but the terrain is more uniform. Tree growth is good, and excellent pastures are maintained by some of the residents.

The soils, like those in the Coopers Rock Area, belong to the GrayBrown Podzolic Soil Group. They have been derived mainly from shales that are finer textured than those on Coopers Rock.

This area lies in the Allegheny series of the Carboniferous system. The iron ore mined here was a carbonate and called "Irondale Ore."

3Personal communication from Walter W. Frazee of Crellin, Maryland, who worked for the Kendall Lumber Company. 
The thicknesses of strata above and below the ore, as determined from a pit opening near Gladesville, follow (8, p. 407).

Rock Strata

Sandstone, massive

Shale, sandy

Limestone, gray and hard

Shale, clark gray

Limestone, ferriferous

"Irondale Ore"

Shale, gray and concealed
FELT IN DEPTII

15

5

6

0.5

67

Thus, shales and limestones were immediately above the iron ore. The high walls of the strippings were less than ten feet in height and sandstones were not observed overlying the shales in the high wall, nor was sufficient sandstone found in the spoil to indicate the preserice of such a stratum. The individual shale fragments were rather thick but weathered rapidly into fine particles.

Mr. Thayer Holmes, the oldest resident of Gladesville, mined iron ore the last two years that the Gladesville furnace was in operation. He was then 15 or 16 years of age, and remembers the ore to be about three feet in depth, overlain by limestone two feet thick.

The Gladesville Area was originally forested. Mature trees and remaining stumps indicate that species of oak and chestnut were abundant. This area also is a portion of the Mixed Mesophytic Forest region, but it does not have the dry ridges and slopes common to the Coopers Rock Area.

Much of the land had been cleared for farming prior to the introduction of the iron industry. Thayer Holmes' father started clearing the forests from his lands about 1850, and other lands had been cleared before that date. Iron ore was mined and hauled to the Gladesville furnace. This furnace commenced operation about 1870 and continued until 1881 (7, p. 114). Many residents of Gladesville, mainly farmers, stopped work on their farms and obtained employment in the iron industry. Their lands remained idle until the furnace closed in 1881. The land was then returned to agricultural uses.

Little is known of the treatment of the forest stands. However, as another large furnace nearby operated intermittently from 1859 to 1882, there is little doubt but that most of the forests were heavily cut for the production of charcoal.

The chestnut blight appears to have attacked the Gladesville Area about the same time as it did the Coopers Rock Area. Increment borings on trees of other species that were released from suppression 
when the chestnuts died show that the chestnuts began dying around 1923 and 1925. (See Figure 18).

Todlay the land within the study area is largely in agricultural use; most of it is in pasture. A portion of the land is in timber, with some stands as old as 70 years. Species of oaks predominate in these older stands.

\section{DESCRIPTION OF UNITS}

Within the Coopers Rock and the Gladesville areas, spoil banks formed when the iron ore was mined, and undisturbed land immediately adjacent to each spoil bank were selected for study. Each spoil bank and the adjacent undisturbed land, used as a control, comprise a unit. Four forested units and two grassland units have been studied.

The units were selected mainly according to the condition of the vegetation and size of the spoil. On the forested spoils an attempt was made to choose banks having at least one important timber species in moderate abundance and growing under adequate conditions of stocking rather than as isolated individuals. Also, spoils containing the oldest stands were used. Grassland units were chosen in which neither spoil nor control have been limed or fertilized. In all instances large spoils were given preference over smaller ones. 


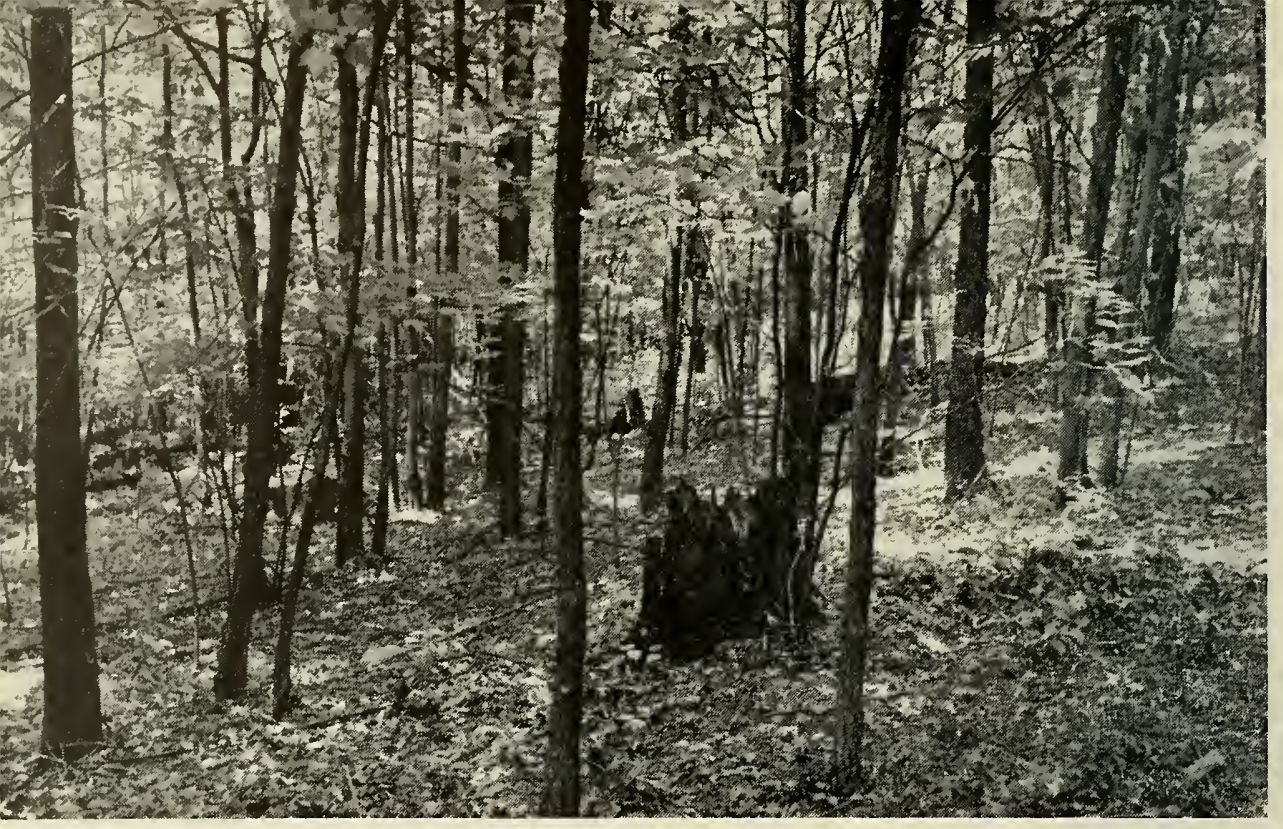

THE QUARRY RUN UNIT is located in the Coopers Rock Area midway up a south slope and at an elevation of 1,900 feet. The spoil bank is estimated to be between 85 and 119 years old, as ore was mined from this unit between 1834 and 1868 . The area of the spoil is 3.7 acres, the greatest width being 70 feet. The soil of the control is in the DeKalb series with a pH of 4.5. The spoil has a pH of 4.4 .

Chestnut oak, white oak, and black oak are the most abundant valuable timber species. The white oaks average 37 feet tall at 29 years. This unit appears to have the poorest site quality of the forested units. The largest trees pictured are white, black, and scarlet oaks, reaching a maximum of 9 inches in diameter. The stems are mainly of sprout origin.

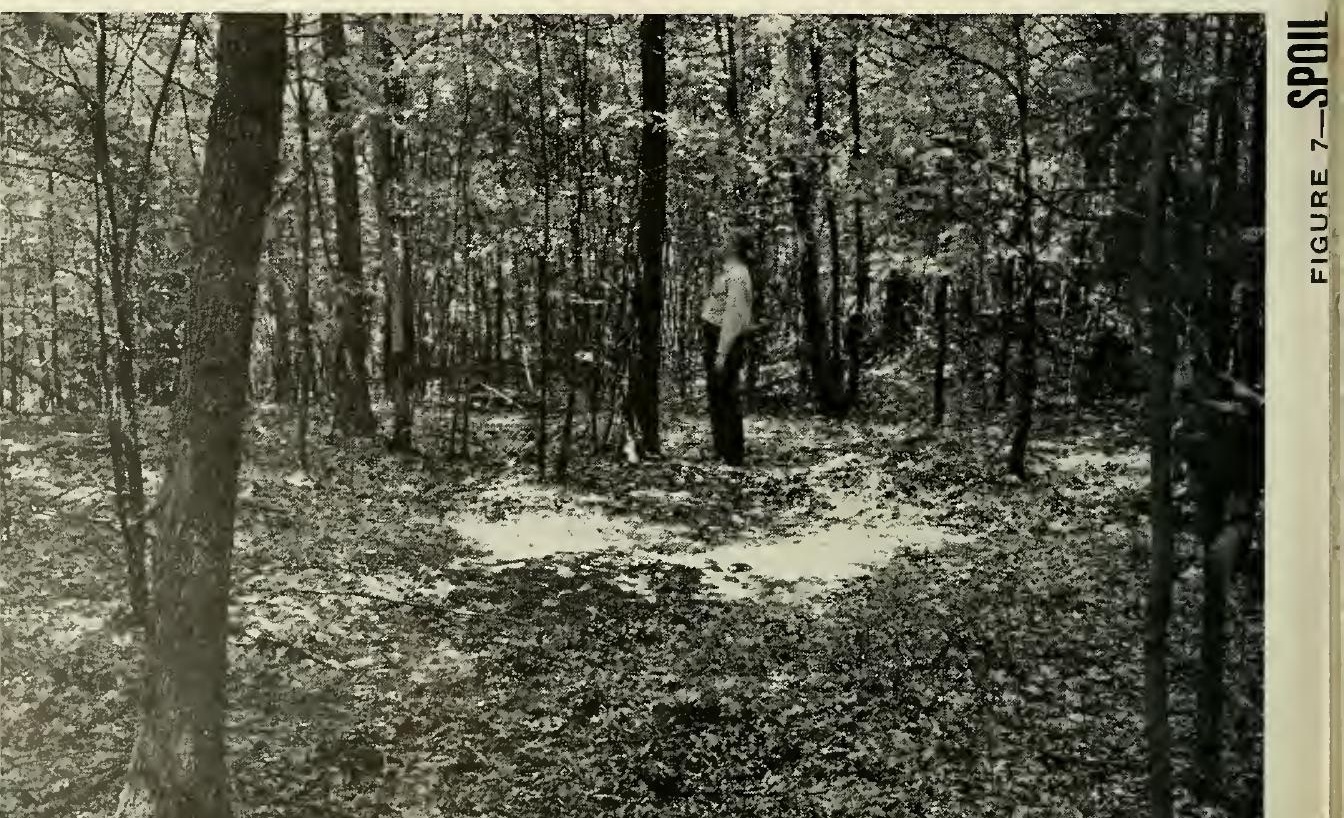




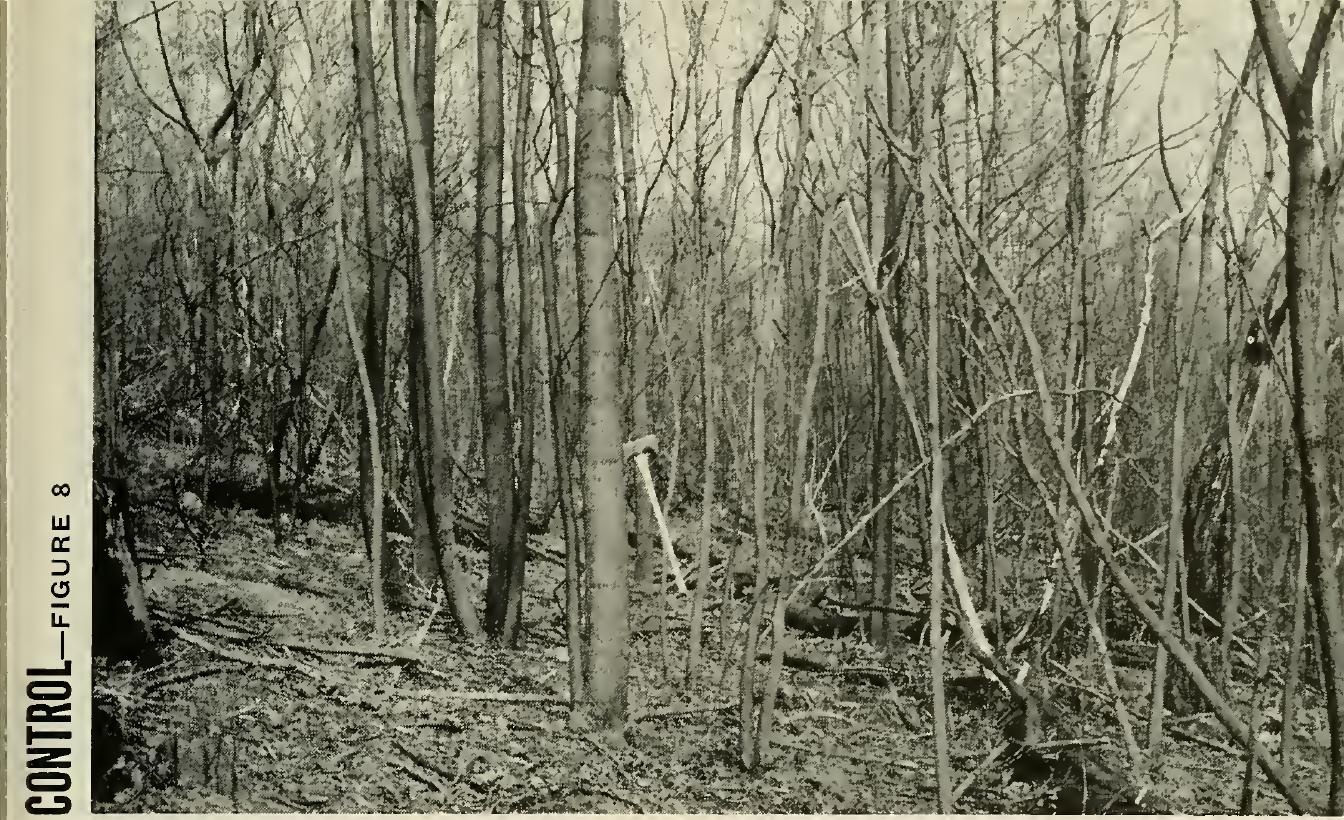

THE JOHNSON HOLLOW UNIT is located on the same hill and at the same elevation as the Quarry Run Unit, but is on the north slope. The iron ore mined in this unit was smelted at the Woodgrove furnace, which operated from 1822 to 1868 . The spoil is estimated to be 85 to 131 years old, having an area of approximately 3.8 acres. The soil of the control is in the DeKalb series with a pH of 5.1. The pH of the spoil is 5.0.

Yellowpoplar predominates in the upper crown class, with black cherry and sassafras being next in abundance. These yellowpoplars reach an average height of 55 feet in 19 years. The rate of height growth and the presence of dense luxuriant herbaceous vegetation indicate a very good site. The yellowpoplar on the control, in which the axe is sticking, is 10 inches in diameter and the one on the spoil, 9 inches. Nearly all trees are of sprout origin.

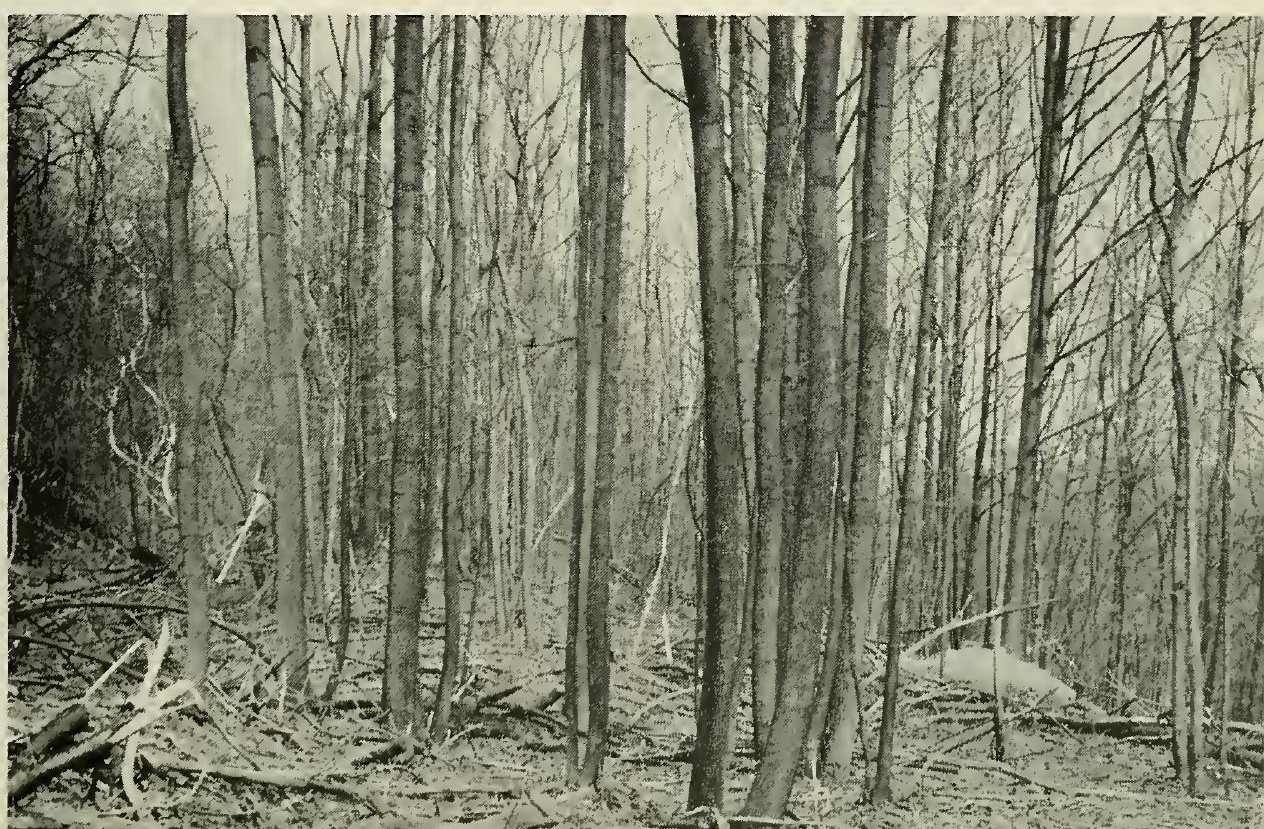




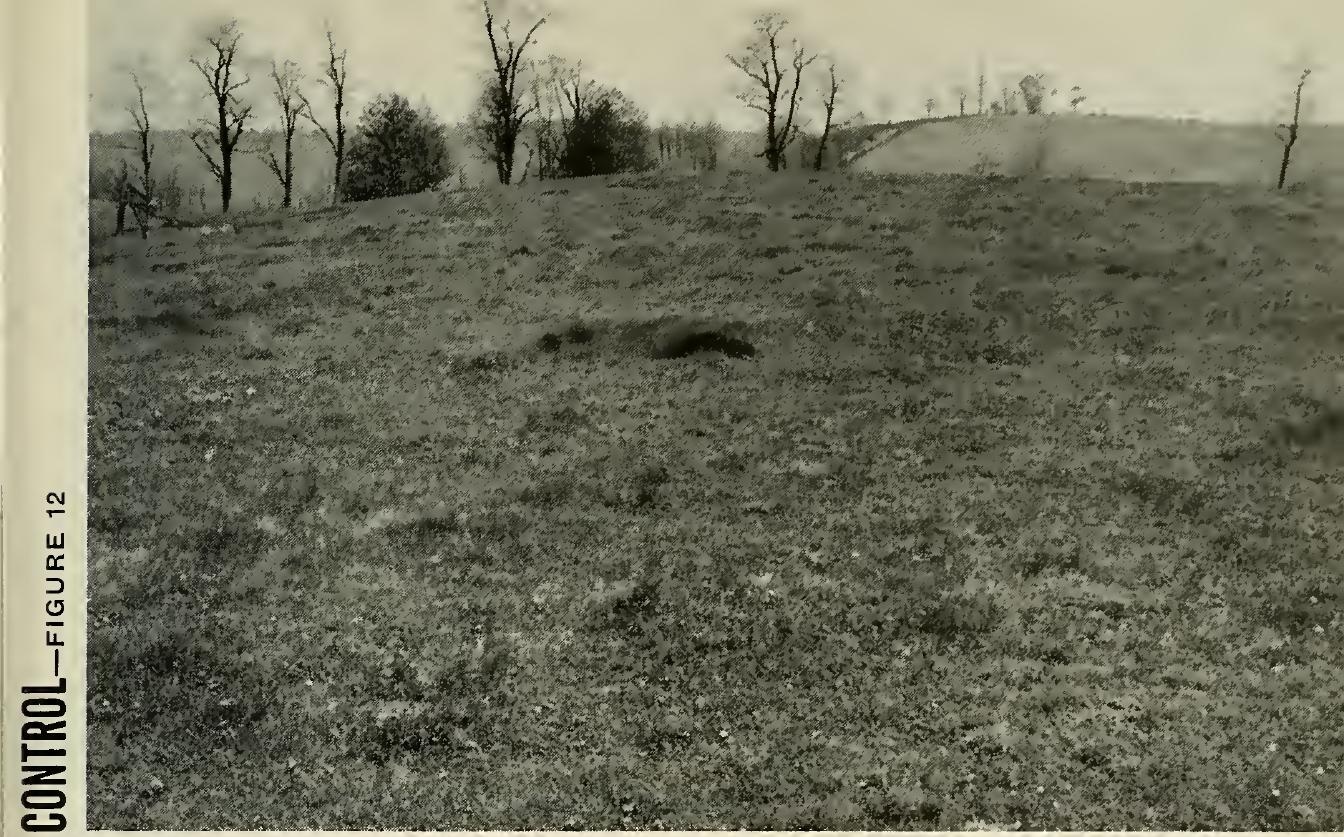

THE PETERS UNIT is located in the Gladesville Area at an elevation of nearly 1,900 feet. The unit comprises the top and upper east slope of a low hill. The spoil is between 72 and 83 years old, and is about 0.6 acres in size. The soil of the unit is in the Westmoreland series. The $\mathrm{pH}$ of the control is 5.0 , and the spoil 4.8 .

The acreage included in the unit has been in pasture since the land was cleared of the original forest. Information obtained from local people indicates that neither the spoil or the control have ever had applications of fertilizer or lime. Kentucky bluegrass and common cinquefoil are in high abundance on the unit. Redtop also is common on the spoil, and povertygrass on the control. Black locusts were observed on the edge of the spoil, and a few stumps of the same species are evident on the main portion of the spoil.

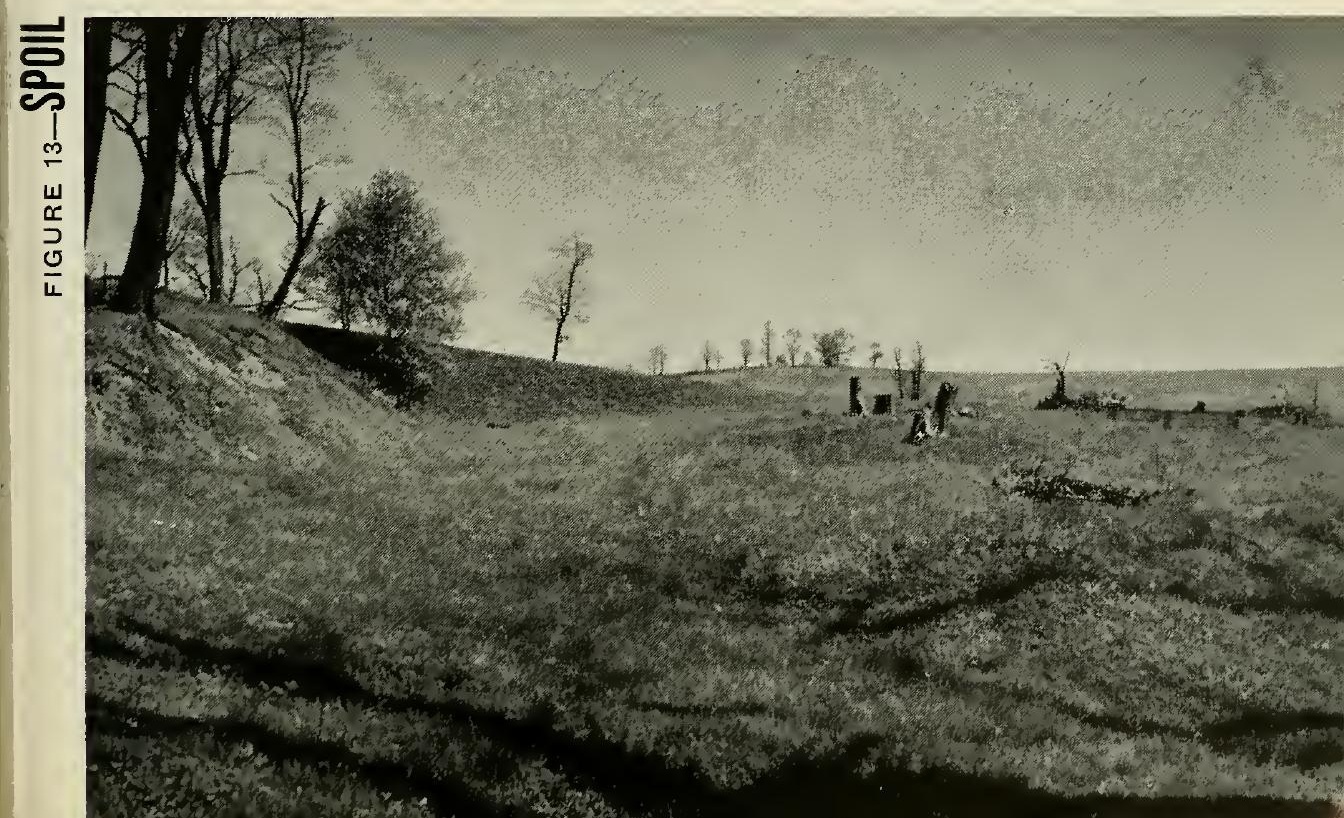




\section{PROCEDURE}

\section{Forested Units}

Abundance of woody vegetation and ground cover was collected from 50-square-meter and 10-square-meter circular plots. The plots were evenly spaced over the spoil banks so that the top and each side of the bank were included equally in the sampling. The distance between plots varied from 0.5 to 1 chain, depending upon the size of the spoil bank. Woody species 0.6 inches and larger in diameter 4.5 feet from the ground were recorded by diameter classes from the larger circular plots. Reproduction, which includes tree species below 0.6 inches in diameter, was recorded from the smaller circular plots which had a common center with the larger plots.

The area sampled by the 50-square-meter plots varied from 12 per cent of the largest spoil to 32 per cent of the smallest, the spoil areas ranging from 3.8 to 0.5 acres, respectively.

Adjacent to each spoil, on undisturbed land, an equal number of plots with similar spacing were established for comparing the abundance of vegetation on the spoil with that growing on the control. From these plots, the number of woody stems and basal area of stems 0.6 inches in diameter and above, and the amount of reproduction were compared on each spoil with the adjacent control. The significance of differences was determined by the $t$-test.

The percentage of ground cover was determined by ocular estimation within the 10-square-meter plots. Although herbaceous plants and low-growing shrubs compose the ground cover (17), mosses were included with the ground cover because they were noted as being fairly abundant on portions of the spoil banks before measurements were taken. The proportion of shrubs, herbs, and mosses within each plot was determined and the species of shrubs and herbs indentified. No attempt was made to test differences in percentages of ground cover between the spoils and controls, as the data were not taken with sufficient accuracy.

The site quality of the spoils for tree production was compared to that of the controls by the use of site index. ${ }^{4}$ For each unit a commercially important species occurring in reasonable abundance was selected. Twenty or more individuals that had not been suppressed, and whose crowns were dominant or codominant, were chosen on each spoil and each control. One exception was the Glen Unit where only

${ }_{4}^{4}$ Height of dominant and eodominant trees at a specified age. Fifty years is commoniy used in the eastern United States, but for this study the mode-age of eaeh unit was used. 
seven suitable trees could be found on the spoil and a similar number were sampled on the control. Height to the nearest foot was measured with the Abney level, and age was determined by counting annual rings of increment cores.

The significance of differences in height between trees on the control and on the spoil was determined in the following manner: For each unit, the age and height data of each tree on the spoil and control were pooled and a regression equation derived of height over age. Either a linear or a second degree equation was selected, depending upon which would produce the better fit. Because the trees were close to the same age a linear curve proved a better fit than the second degree curve for all but one unit, and that one had a wider range of ages than the others.

Deviations in height from the regression were summed and averaged for the spoil and control separately. Thus the height-difference in feet between trees growing on the spoil and on the control was determined. The standard error of this difference was next computed, and the significance of difference determined by the $t$-test.

\section{Grassland Units}

Species abundance and amount of forage production were compared on the grassland spoils and controls.

Abundance of species was determined by the inclined point quadrat method (18). These data were obtained at twenty or more stations evenly distributed over the area of each spoil and each control. This number was sufficient to give reliable information on the composition and abundance of such vegetative species, according to $\mathrm{S}$. A. Cain's method (12, p. 44). The principal comparison of species abundance between spoil and control was made with desirable forage species. Clovers, timothy, Kentucky bluegrass, Canada bluegrass, and redtop were considered to be such species (13, p. 2I).

Forage production was determined by weight of vegetation produced. As the spoil and controls were grazed, wire cages, one square meter in size, were placed over each plot for protection. Three plots were selected on each spoil and each control, and the cages put in place well before the 1951 growing season began. The lorage crop was clipped at ground level on July 14 and again on November 9, 1951. The material from each plot was then oven-dried at $105^{\circ} \mathrm{C}$. and weighed. No attempt was made to determine significance of the data because of the small sample. 


\section{RESULTS OF INVESTIGATION ON FORESTED UNITS Comparison of Composition of Vegetation On Spoils with Adjacent Controls}

The four forested units, which include the Chestnut Ridge, Quarry Run, Johnson Hollow, and Glen units, have been described briefly and are illustrated in the section Description of Units. Since differences occur between units in age of stand, composition of vegetation, and character of soil, most of the comparisons of control with spoil will be presented by units.

Abundance of Woody Vegetation 0.6 Inches in Diameter and Above

The number of stems per acre, basal area per acre, and abundance of species 0.6 inches in diameter and above for both spoil and control are presented in Table 1 for each of the four units.

The summary at the bottom of Table 1 indicates that in only one instance does a real difference exist in number of stems per acre between spoil and control, that being in the Quarry Run Unit. This unit has a higher number of stems on the control than on the spoil. However, the basal area does not differ significantly between the spoil and control on any of the units. Therefore, the spoils are quite comparable to the controls in both number of stems and in basal area per acre.

The number of different species represented on the spoil and control is quite alike when compared by each individual unit. Also, many of the species present in highest abundance on the spoil are high in abundance on the control, although some differences exist. Table 1 shows that on the Chestnut Ridge Unit black birch is high on the spoil and low on the control, whereas staghorn sumac is relatively higher on the control than on the spoil. On the Johnson Hollow Unit yellowpoplar is in greater abundance on the spoil. The greatest difference between abundance of species may be noted on the Glen Unit, which also is the smallest unit. Here, hickory is considerably higher on the control than spoil, whereas black cherry and witchhazel are fairly abundant on the spoil but were not found on the control.

Even considering the few differences, there is no indication of the spoil being a better or poorer site as determined by species composition.

The abundance, as determined by basal area, also is in close agreement with abundance as determined by number of species in the stands of these four even-aged units. However, on the Chestnut Riclge Unit the basal area of black cherry is greater than the abundance as based 


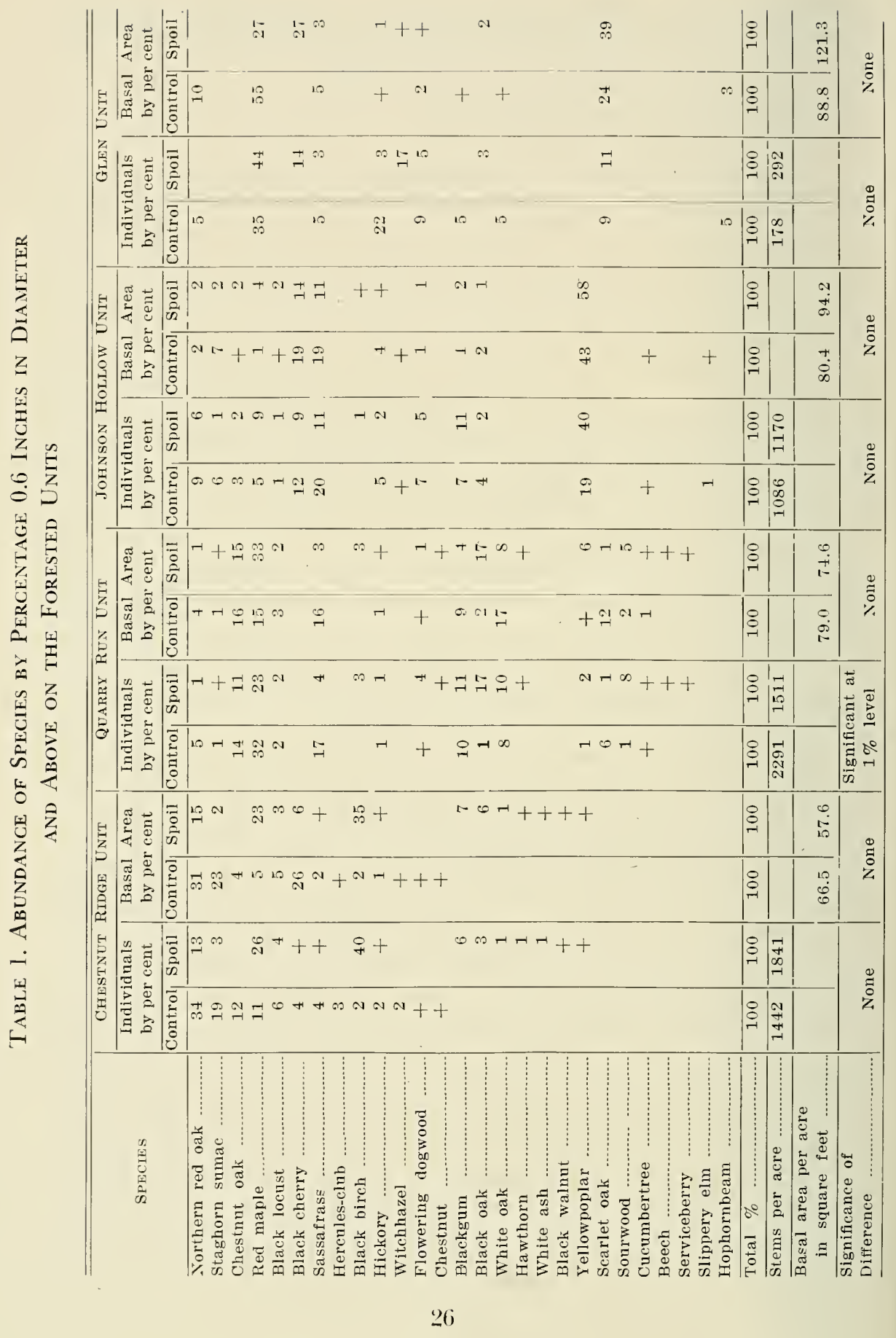


on number of stems, indicating the larger size of the black cherry on that unit. Yellowpoplar on the Johnson Hollow Unit is higher when expressed as basal area than when expressed as number of stems, again indicating the larger dianeter of the yellowpoplar in relation to other species. On the Glen Unit hickory and witchbazel are higher in abundance when expressed as number of stems than when expressed as basal area. This indicates that many individuals of those two species are in the small diameter classes. Scarlet oak is higher in abundance when expressed as basal area, indicating relatively fewer but larger trees of scarlet oak on this unit.

The close agreement of number of stems per acre, basal area, and composition of species between the spoil and control indicates that during the period of 72 to 131 years, which is the time elapsed since these spoils were formed, the composition of the larger woody vegetation on the spoil has become similar to that of the surrounding area.

\section{ABUndance of Reproduction}

The abundance of reproduction, which includes stems of woody species less than 0.6 inches in diancter for the four forested units, is presented in Table 2.

The summary at the bottom of Table 2 presents the number of stems per acre of reproduction for both spoil and control. No real difference exists between the number of stems in the control and spoil for the Chestnut Ridge, Jolınson Hollow, and Glen units. The Glen Unit spoil contained about two and one-half times as many individuals as did the control. This difference was not significant because of the high variability in number of stems between plots. However, the number of stems on the control of the Quarry Run Unit was significantly higher than on the spoil. A similar trend in number of larger trees has already been noted on this unit in Table 1, as the control contained significantly more stems per acre than the spoil. The reproduction is largely of seedling origin, which is in contrast with the sprout origin of the larger trees on the Chestnut Ridge, Quarry Run, and Johnson Hollow units.

The number of species in the reproduction class on the spoil slightly exceeds the number on the control on all but the Glen Unit, on which the number is equal. Species that predominate are black cherry, sassafras, and red maple. Of these three species only sassafras is consistently more abundant on one condition than the other for all four units, this species being more numerous on the controls than on the spoils.

The principal information that may be obtained from the study of the abundance of reproduction is that it is much alike on spoil and 


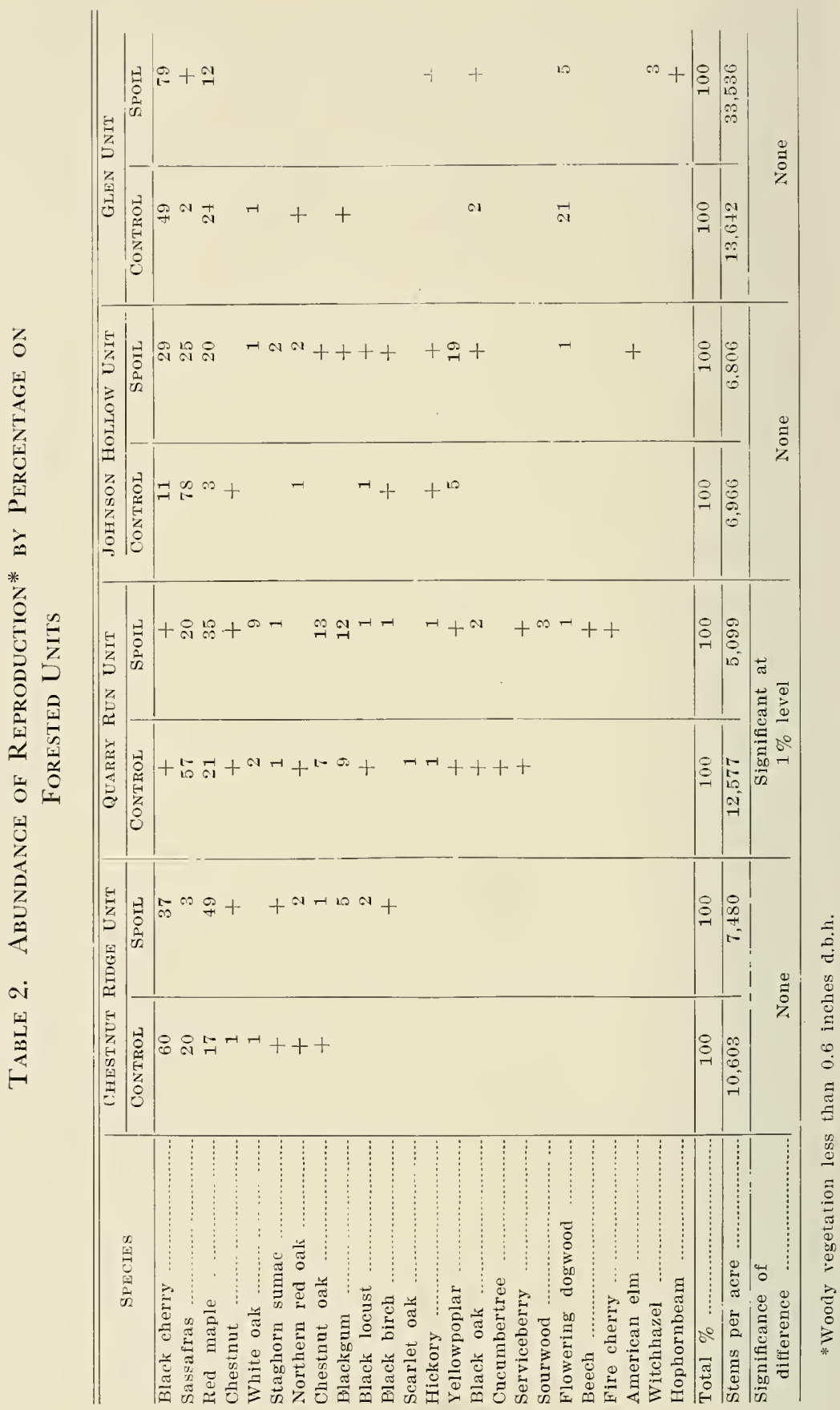


control. Such a similarity is to be expected because the older woody vegetation is also similar on spoil and control of each unit.

\section{Abundance of Ground Cover}

The ground cover, as used here, includes herbaceous plants, lowgrowing shrubs, and mosses. Ocular estimates of the percentage of ground covered by such small plants were made in small plots on the spoil and control. The abundance of shrubs, herbs, and mosses was then determined by estimate. The species of shrubs and herbs highest in abundance observed in each plot were recorded.

Percentage of ground cover and relative amounts of shrubs, herbs and mosses comprising the ground cover are presented in Table 3 for the foum forested units. These data were gathered during July and early August when the development of such vegetation is at its maximum.

The averages of percentage of ground cover, and the three components of ground cover, between the control and spoil are all very close. The greatest difference occurs in the amount of mosses, with the spoil having a greater amount than the control. Although statistical analyses were not attempted because accurate measurements were not used, it is evident that a real difference between percentage of ground cover on the control and spoil does not exist.

Table 3. Comparison of Ground Cover Between Spoll and Control FOR EACH UNIT

\begin{tabular}{|c|c|c|c|c|c|c|c|c|}
\hline \multirow{3}{*}{ UNIT } & \multirow{2}{*}{\multicolumn{2}{|c|}{$\begin{array}{l}\% \text { Ground } \\
\text { Cover }\end{array}$}} & \multicolumn{6}{|c|}{ Ground Cover } \\
\hline & & & \multicolumn{2}{|c|}{$\%$ SHrubs } & \multicolumn{2}{|c|}{$\%$ HERBS } & \multicolumn{2}{|c|}{$\%$ Moss } \\
\hline & Control & Spoil & Control & Spoil & Control & Spoil & Control & Spoil \\
\hline Chestnut Ridge & 40 & 25 & 8 & 4 & 91 & 83 & 1 & 13 \\
\hline Quarry Run & 9 & 1.5 & $4 \mathrm{~S}$ & 52 & 51 & 39 & 1 & 9 \\
\hline Johnson Hollow & 75 & 57 & 16 & 20 & 79 & 77 & 5 & 3 \\
\hline Glen & 24 & 31 & 41 & 2 & 59 & 95 & 0 & 3 \\
\hline $\begin{array}{l}\text { Weighted average } \\
\text { by area }\end{array}$ & 34 & 31 & 33 & 31 & 65 & 62 & 2 & 7 \\
\hline
\end{tabular}

The species of shrubs and herbs observed on the control and spoil also are quite similar. They are presented for the Johnson Hollow Unit in Table 4. This unit was chosen to represent the similarity found on all units because of its large acreage and high percentage of ground cover. 
Table 4. Distribution of Shrubs and Herbs in Ground Cover* in Order of Dimishing Abundance on the Johnson Hollow Unit ${ }^{\dagger}$

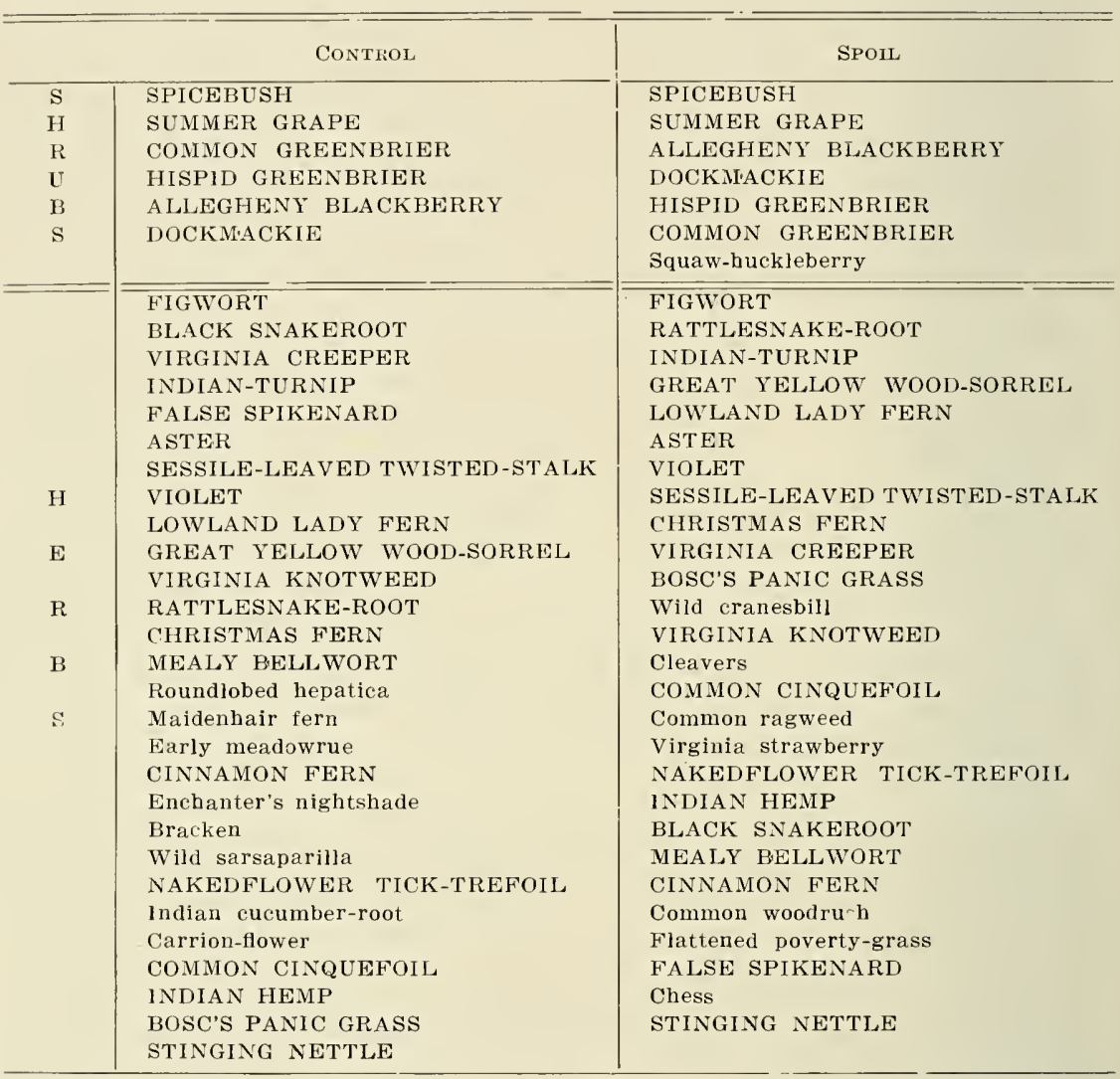

* Mosses are not included in table as they were not identified. However, they were present on both control and spoil.

$\dagger$ Species common to both spoil and control are in capitals.

Table 4 shows that the shrubs common to control and spoil are quite similar, all six of the species noted on the control being present on the spoil also.

The occurrence of species of herbs on the spoil also is in close agreement with those found on the control. Seventy-four per cent of all the species found on the spoil were observed on the control.

A comparison was made of the twelve most abundant species of herbs on spoil and control and 91 per cent of these species observed on the spoil also were present on the control.

The abundance of species of herbs and shrubs on the spoil and control for the Chestnut Ridge, Quarry Run, and Glen units also were 
in close agreement. This indicates that factors of site important for the presence of the herbs and shrubs are much alike on both spoil and control.

Figure 16 shows a view of the ground cover on the Johnson Hollow spoil as it appeared the first week in August.

\section{Comparison of Site Quality of Spoils with Adjacent Controls}

Site Index Determination

The site quality of the spoils and controls was measured by site index, using the heights of dominant and codominant trees at the modeage, which is the age of the greatest number of sample trees on the unit. This age happened to be different on each unit. The species chosen to test the site quality was a commercially important one present on both spoil and control. The maximum and minimum ages and mode-age of the trees sampled for each unit are shown in Table 5.

On most of the units the range of ages of sample trees was small, and in all instances the age of the majority was close to the mode. The greatest difference in ages occurred on the Quarry Run Unit where the difference between the maximum and minimum age for white oak was 33 years.

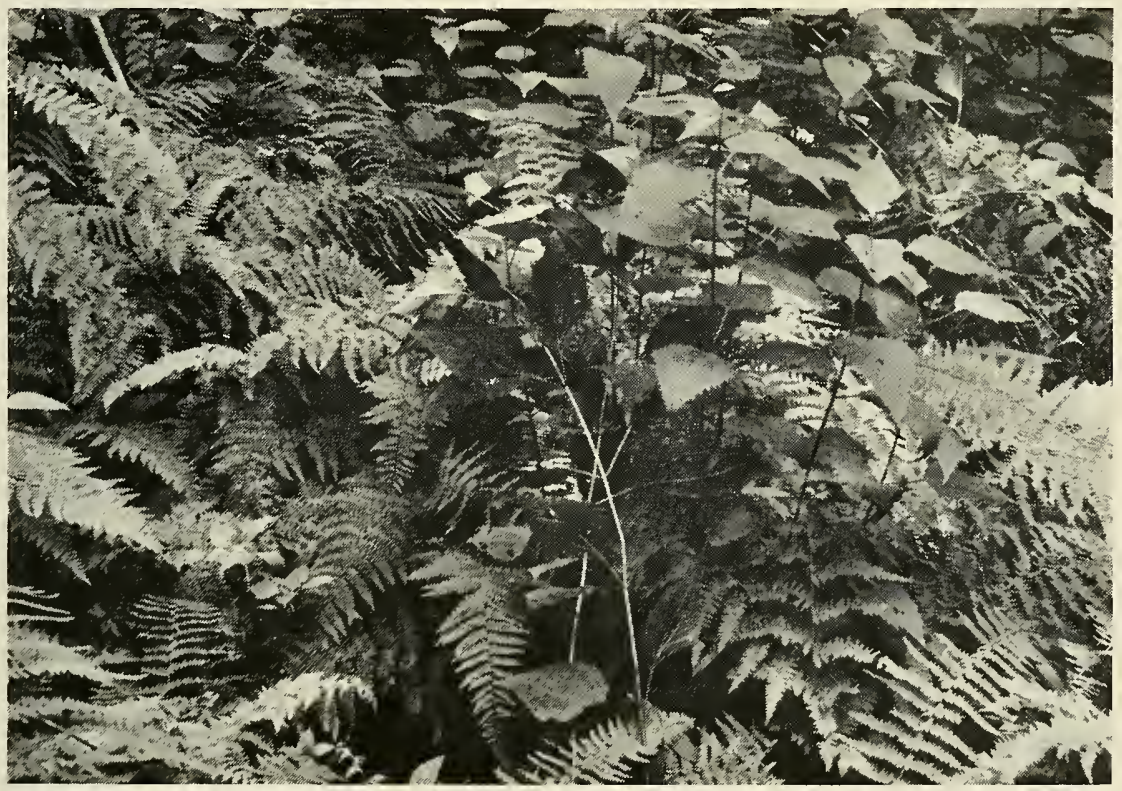

FIGURE 16. GROUND COVER on Johnson Hollow Spoil. Taken the first week of August when herbaceous vegetation is well developed. 


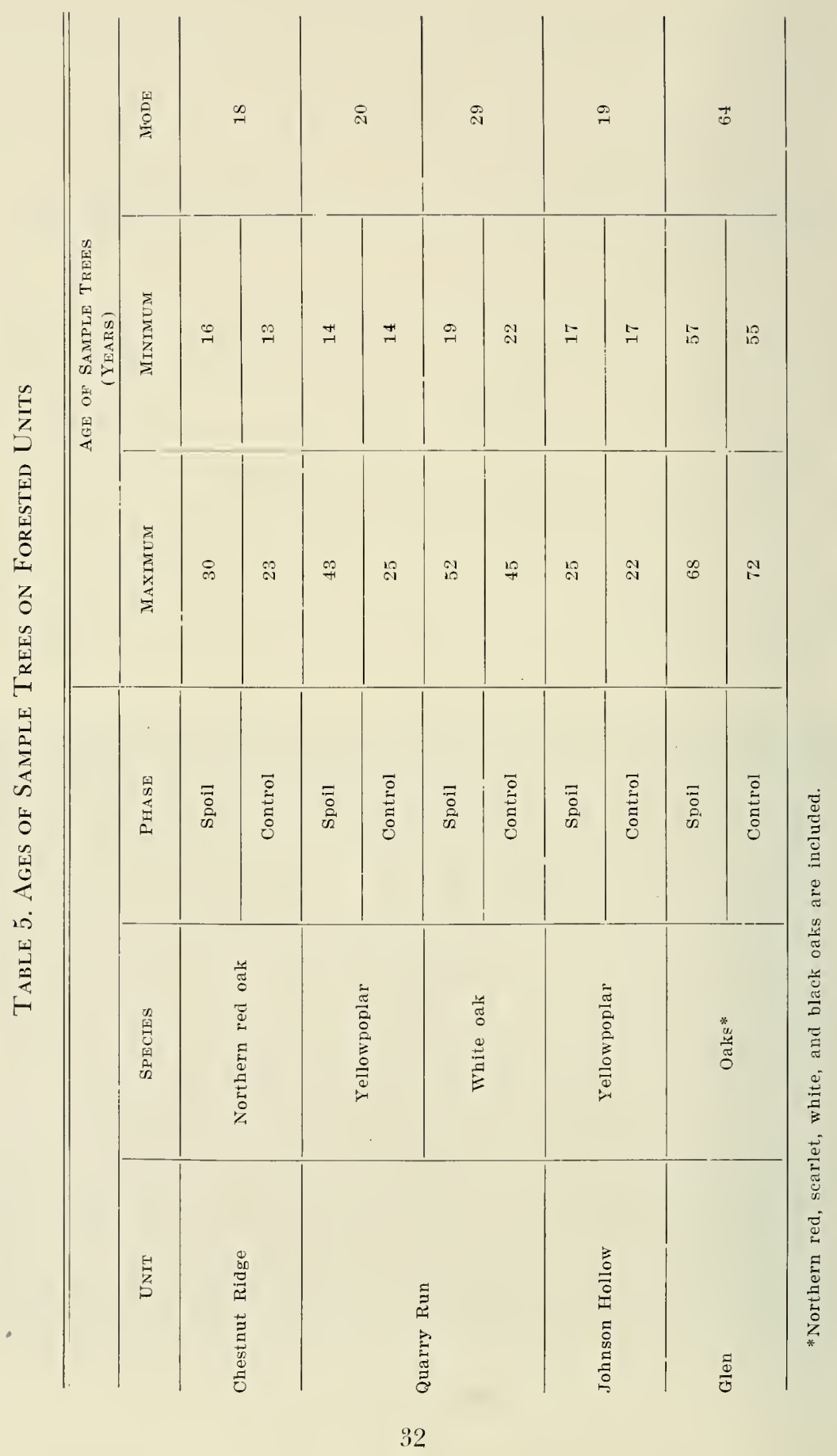


The difference in site index between the control and spoil was determined statistically as described in Procedure. As different species were used and conditions of site varied between units, each unit has been treated separately. Table 6 summarizes the significance of differences between site index of the test species on the spoil and control for each unit. Also, the number of sample trees and base-age are given for the species.

Northern red oak was the species tested on the Chestnut Ridge Unit. The base-age used in the determination of site index was 18 years, although ages varied from 13 to 30 years. The site index on the spoil was 29.7 feet, compared to 32.5 feet on the control. The difference of 2.8 is significant at the 5 per cent level, indicating that the control is a better site than the spoil.

Yellowpoplar and white oak were both tested on the Quarry Run Unit because both species were present in sufficient amounts. A base-age of 20 years was used for the yellowpoplar and ages varied from 14 to 43 years. The site indices of 44.2 feet on the spoil and 45.1 feet on the control were not statistically different. A base-age of 29 years was used for the white oak which varied from 19 to 52 years on the unit. The site indices of 36.6 and 38.0 feet for the spoil and control, respectively, did not differ significantly. Thus no difference in site was evident between the spoil and control on this unit.

Yellowpoplar, which composes most of the upper crown classes, was chosen to test site quality of the Johnson Hollow Unit. The base-age was 19 years, actual ages varied from 17 to 25 years. The site index on the spoil was 56.6 , compared to 52.8 feet on the control. The difference of 3.8 feet is significant at the 1 per cent level, indicating a better site quality on the spoil than on the control.

The spoil of the Glen Unit is smaller in area (0.5 acres) and as the trees in the upper crown classes are from 57 to 68 years old fewer trees could be found suitable for determination of site index than on the spoils of the other units. The only selection that could be made was species of oaks which included northern red, scarlet, black, and white. Only seven trees were found suitable on the spoil. These were compared with seven on the control. The resulting site index of the spoil at 64 years was 69.9 leet and of the control at the same age was 57.9 feet. The differcnce of 12.0 feet proved significant at the 5 per cent level. However, conditions on the control had not been the same as on the spoil throughout the life of the stand. Many chestmut trees had been on the control, and when the oaks were young they were crowded and probably overtopped. As a result they grew very slowly. When the chestnut blight hit, the oaks were released and grew much better. Figure 17 shows stumps of the chestnuts on the control. These chest- 


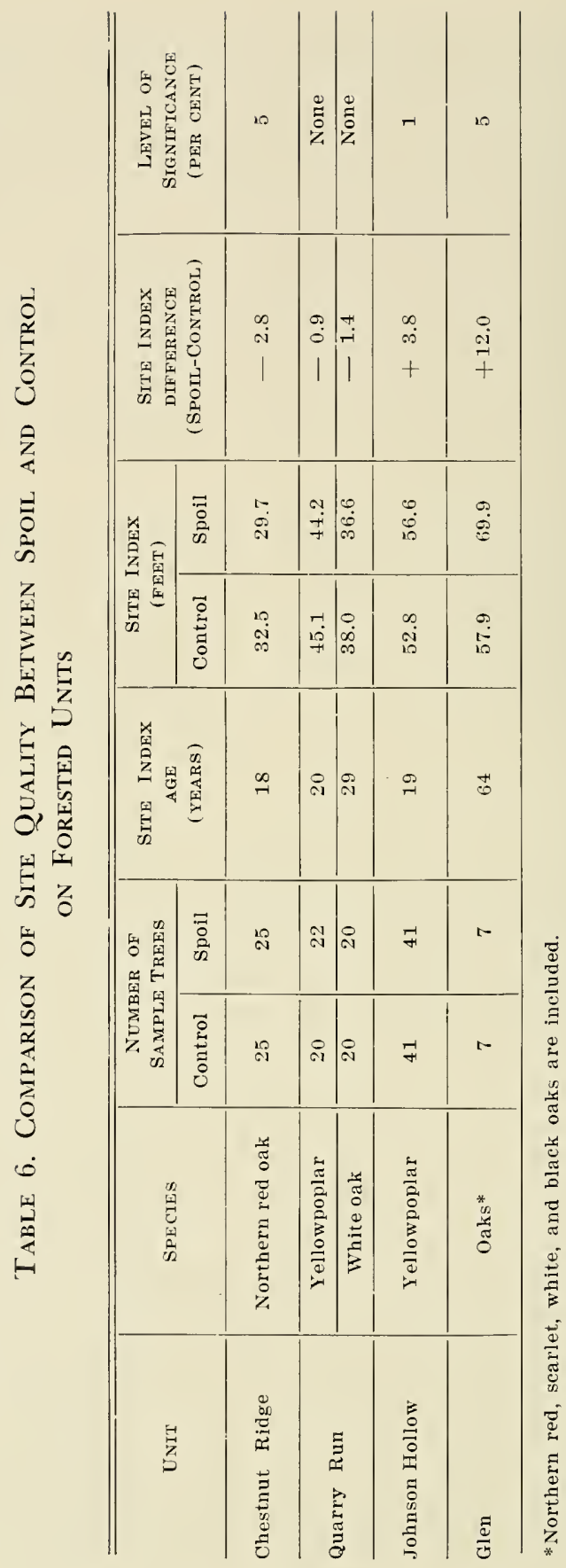




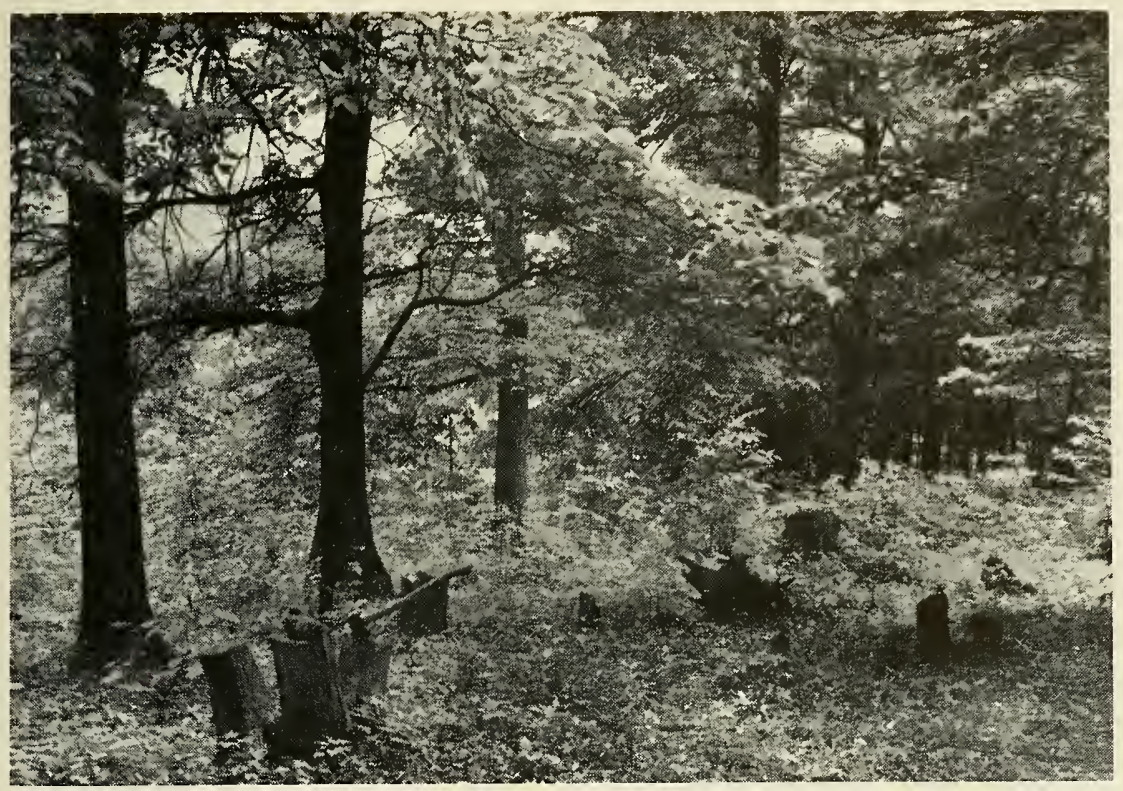

FIGURE 17. OAKS on Glen Control. Stumps of chestnut trees which suppressed the oaks when they were young may be observed.

nuts competed with and probably overtopped the oaks. In Figure 18 is an increment core taken from the oak tree standing at the extreme left in Figure 17. The suppressed rings near the center of the tree were formed when the chestmut was alive, and when release occurred by the dying of the chestnut, about 1925, diameter growth of the oak improved. With such early suppression in diameter growth, it seems reasonable to assume that height growth also was reduced. Therefore, the lower site index on the control is considered partially, and perhaps largely, a result of early suppression of the sample trees, and is not a true indication of a poorer site quality on the control than on the spoil.

Under such conditions, using trees partially suppressed in their youth on the control, and four species of oaks totaling seven individuats on the spoil and seven on the control nuay be justly criticized. The reason for accepting such conditions is that this is the only spoil that could be located where trees of such size occurred. It cloes seem reasonable, however, to assume that on this unit growth is as good on the spoil as on the control.

FIGURE 18. INCREMENT core of oak growing on Gien Control. This core was taken from the left-hand tree in Figure 17. The arrow indicates the 1926 growth ring. Observe the wider growth rings after this date, indicating faster growth after release by the dying of chestnuts. 
The density of stocking of a stand is known to influence height growth with a resulting effect on site index determination. Recent studies by Ralston (15) in the southeast and by Gaiser and Merz (6) in Ohio have shown that height growth of stands is affected by density of stocking. Every effort was made on all units to select sample trees growing in comparable stand densities. There were no significant differences in basal area between spoil and control on the four units as indicated in Table 1. All sample trees were growing in apparently fully stocked stands except on the control of the Glen Unit where openings had occurred as the chestnuts died.

A comparison of the site quality of the control and spoil, by units, is presented in Figure 19 by means of site index curves pertaining to the general area. ${ }^{5}$ The high site quality of the Johnson Hollow Unit for yellowpoplar may be noted on the yellowpoplar site index curves. Also, the site quality of the Glen control, as determined by the site index at a base age of 64, indicates satisfactory growth for the oaks on the mixed oak curves. The satisfactory growth of the oaks on this spoil is of particular importance because this spoil, though small, was the only one found supporting a forest stand approaching maturity. Also, an adequate comparison of growth on the spoil with that on the control cannot be made on this unit due to the differences in conditions affecting growth on the control as compared with the spoil.

\section{Growth of Individul Large Trees}

The site quality of the Chestnut Ridge, Quarry Run, and Johnson Hollow units was determined by the site index of stands of young trees, the base-age used varying from 18 to 29 years. These stands were young to use in making predictions of the capacity of the units, and particularly of the spoils, to produce a mature timber crop. Also, the stands on the spoils began life after the original spoil material had time to build up in nitrogen. (Nitrogen is low when the banks are first formed.) Thus the growth of these stands is not necessarily comparable to growth of stands originating on newly-formed spoils. In order to obtain information on the ability of trees to grow on these spoils beyond the 29-year maximum used in the site index determinations, the width of annual rings of individual large trees and chestnut stumps was investigated.

On these three spoil banks a few trees were found that were considerably larger than those in the dominant and codominant crown classes used in the site index determination. Such trees had been left when the area was logged, and had survived fires. Most of these larger

5Site index curves constructed by C. A. Nyers from data obtained on Coopers Rock State Forest. 

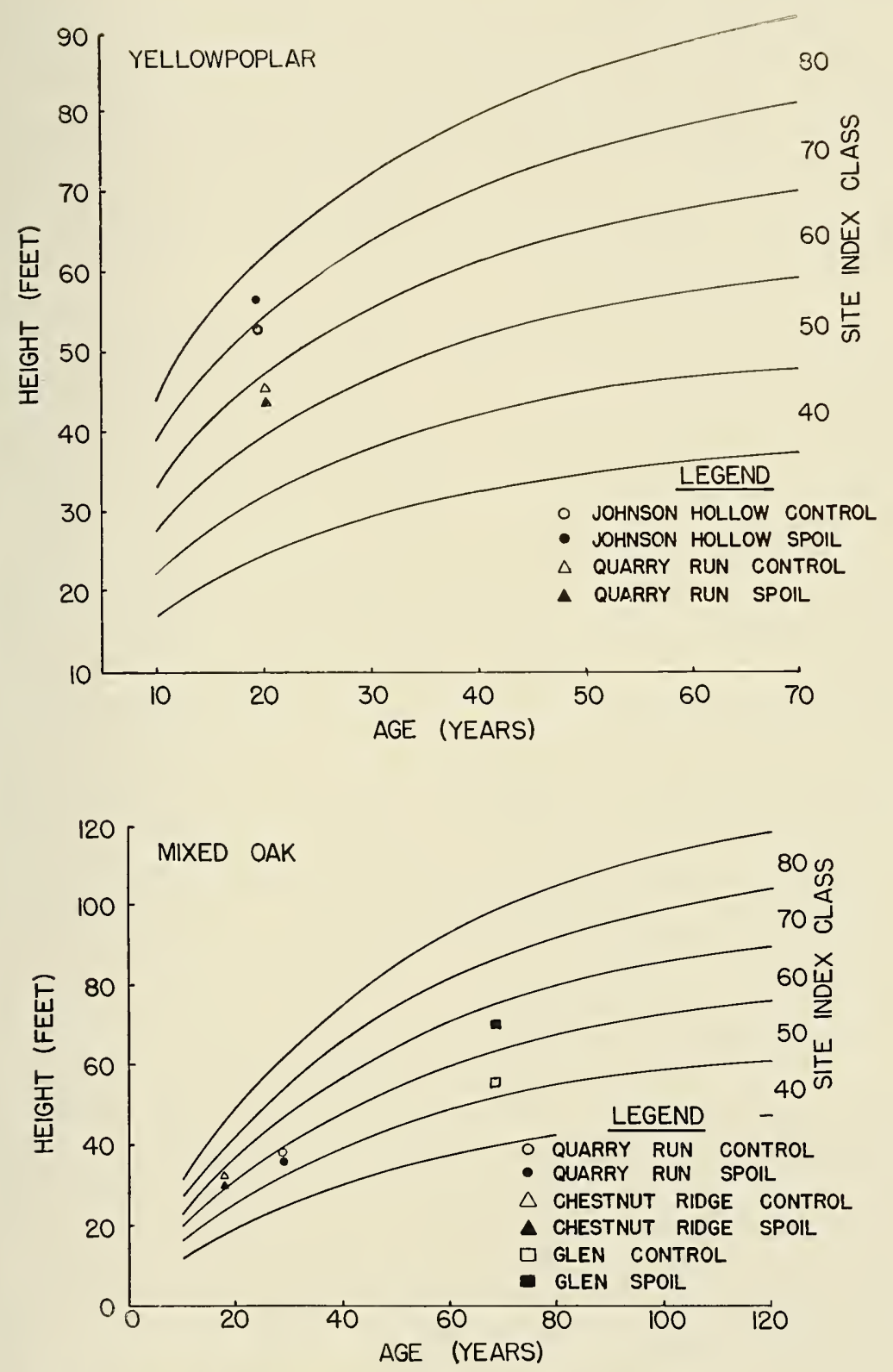

FIGURE 19. SITE INDEX of spoil and control with each unit. 
trees have poor lorm, and all have developed large crowns. They are useless as timber trees.

These large trees give an indication that trees can be established on young spoils and that continued growth can be expected on the spoils for a considerably longer period than the 18 to 29 years used in the site index determination. However, because these trees have not developed under forest conditions, at least during the latter part of their life, they should not be used to predict growth of a forest stand. They merely indicate that trees can grow on these spoils beyond the twentynine-year maximum studied.

In order to get an indication of the recent rate of growth of these large trees, the width of the annual rings recently laid down was investigated. The site quality of trees cannot be determined accurately by diameter or radial growth because such factors as density of stocking and size of crown have considerable effect on this growth rate. However, an indication of the site quality may be obtained by diameter growth where severe crowding or suppression has not taken place.

The recent rate of growth of these large trees was studied by determining the number of annual rings in the last inch of radial growth. Table 7 presents the radial growth of trees over 15 inches in diameter on the three spoils. The largest tree, a 36.5-inch northern red oak, is shown in Figure 20. The number of rings in the last inch of these large trees is surprisingly low, especially for yellowpoplar, red maple, and black cherry, which indicates fast diameter growth. The growth of the oaks is somewhat slower, particularly on the Quarry Run spoil, but still is not poor. Of course, the unusually large crowns of the trees are a big factor in the production of such diameter growth, and under forest conditions diameter growth would presumably be much less on similar sites.

\section{Radial Growth on Old Stumps}

A sufficient number of chestnut stumps was present on both the spoil and control of the Chestnut Ridge, Quarry Run, and Johnson Hollow units to allow an investigation of the diameter growth rate when the trees were living. These stumps are the remains of chestnut trees cut during the logging operation of 1924-25, and many stumps are in such condition that the age may be readily determined and radial growth accurately measured although all are fire-charred. A typical chestnut stump is shown in Figure 2I. Stumps of other species have disappeared, except a few large oak stumps. These are badly clecayed.

The ages of many of the stumps on the spoil indicate that the trees originated soon after the spoil was formed. Table 8 shows the 


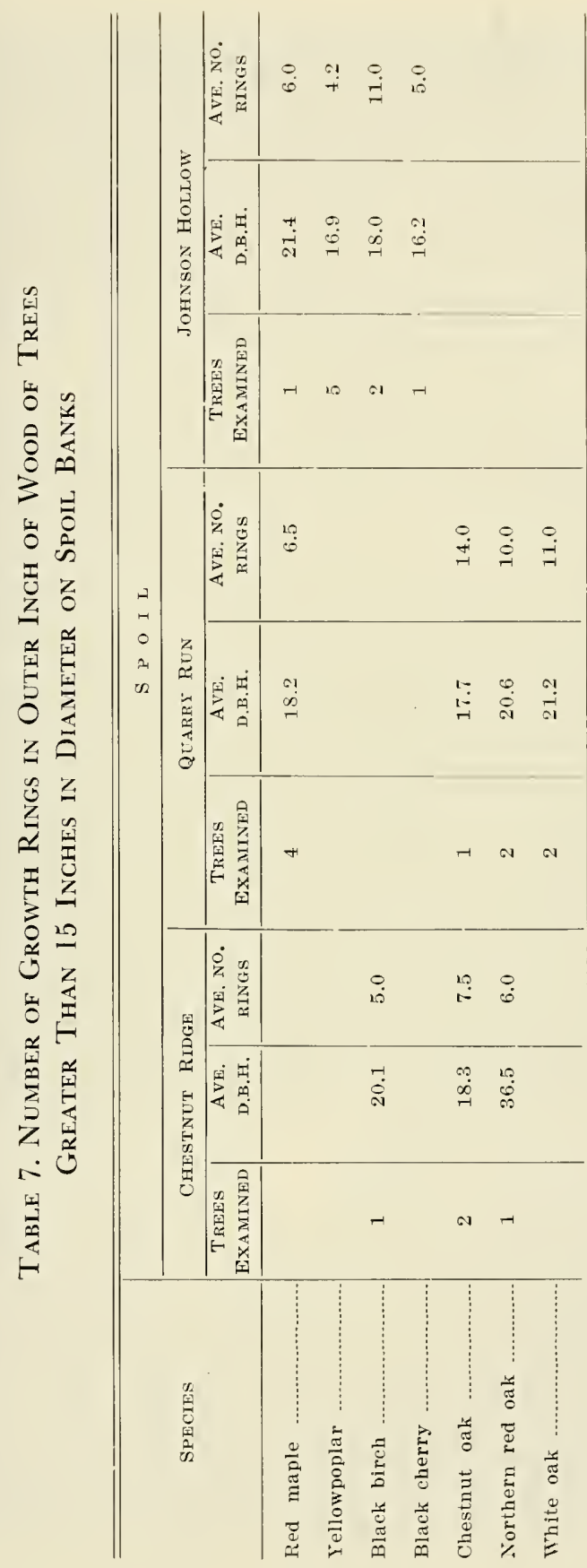




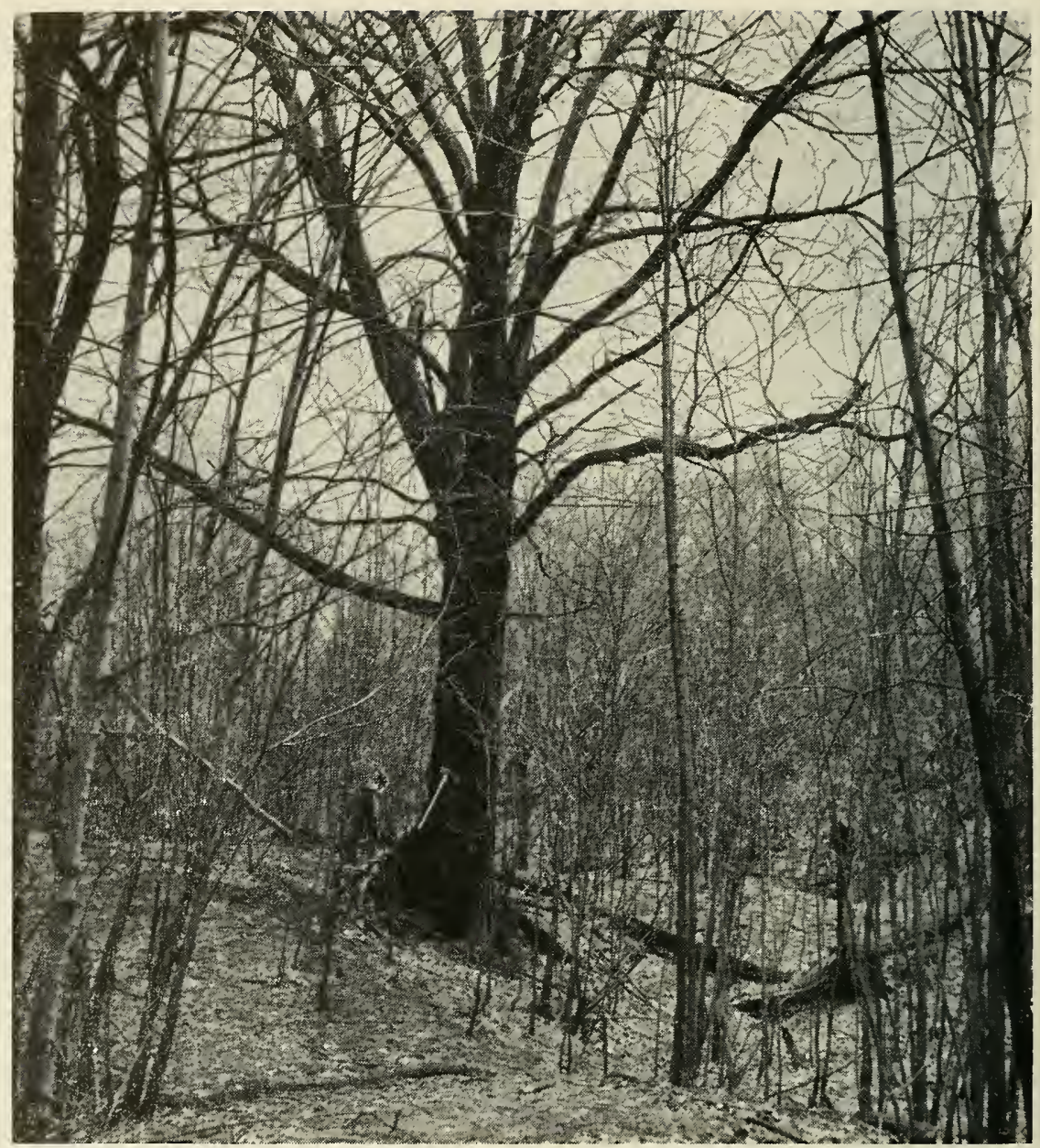

FIGURE 20. A 36.5-inch northern red oak growing on Chestnut Ridge Spoil.

age of stumps and age of their origin as seedlings in relation to the age of the spoils.

lt may be observed from the table that the older stumps that originated as seedlings between 104 and 110 years ago date back nearly to the beginning of the origin of the spoils, which, as well as can be determined, was between 119 and 131 years ago.

An examination of the stumps should show if growth of the chestnut has been poor or satisfactory throughout the life of these trees, and it will be of particular interest to find out if the growth rate of chestnuts on the spoils slowed down appreciably by the time they 
Table 8. Age of Chestnut Stumps on Spoils and Age of Tilfir Origin as Seedilngs in Relation to Age of Spoil

\begin{tabular}{|c|c|c|c|c|}
\hline SPOIL & $\begin{array}{l}\text { AGE OF } \\
\text { STUMPS } \\
\text { (YEARS) }\end{array}$ & $\begin{array}{l}\text { YEARS } \\
\text { SINCE } \\
\text { LOGGINA }\end{array}$ & $\begin{array}{c}\text { AGE OF } \\
\text { STUMP ORIGIN } \\
\text { AS SENDLINGS } \\
\text { (YEARS) }\end{array}$ & $\begin{array}{l}\text { AGEOF } \\
\text { SPOIL } \\
\text { (YLARS) }\end{array}$ \\
\hline Chestnut Ridge & $40-75$ & 29 & $69-104$ & $85-119$ \\
\hline Quarry Run & $25-78$ & 29 & $54-107$ & $85-119$ \\
\hline Johnson Hollow & $40-81$ & 29 & $69-110$ & $85-131$ \\
\hline
\end{tabular}

reached 46 to 60 years of age when they were making heavy demancis for moisture and nutrients. Chestnut stumps with clearly distinguisisable anmual rings were selected on the Chestnut Ridge, Quarry Run. and Johnson Hollow units. Radial growth was measured on each stump from the center outward, using number of rings per inch to indicate growth rate. The data from each stump were combined by one-inch classes, starting at the center, for stumps on the spoils and on the controls. The number of rings was averaged for each inchgroup regardless of the diameter of the stump. Consequently, a greater number of stumps are represented in the smaller one-inch classes, than in the larger.

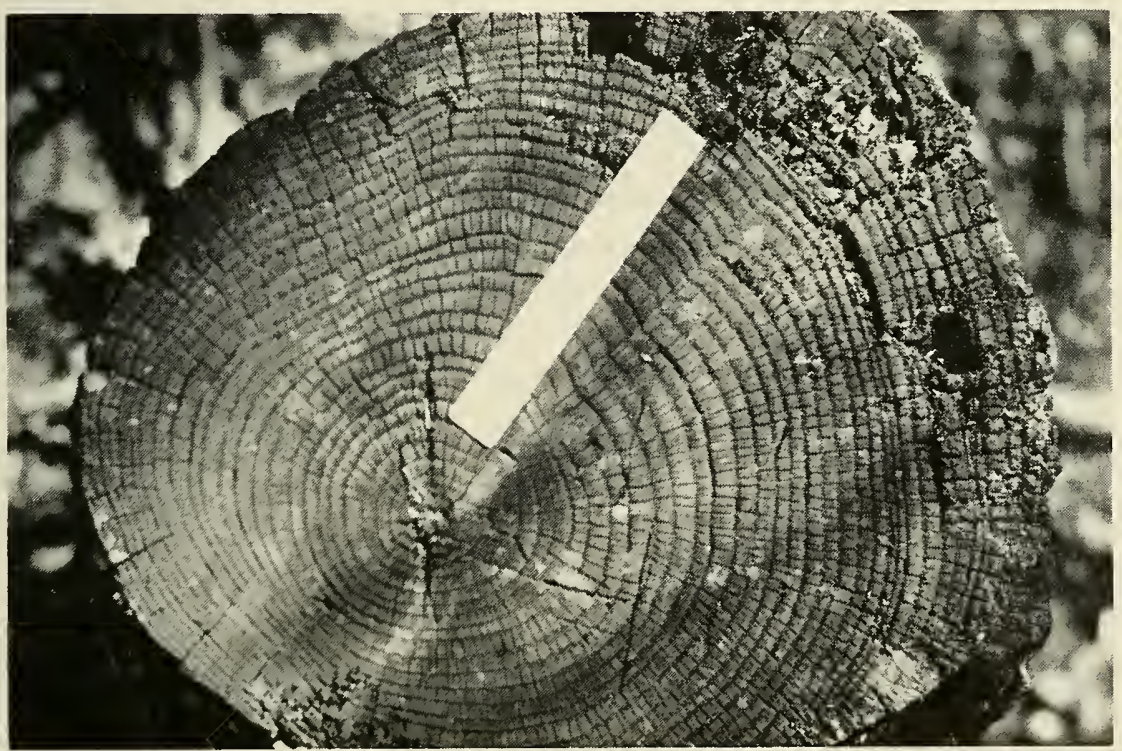

FIGURE 21. CHESTNUT stump on Chestnut Ridge Spoil. Forty annual rings are evident. 6-inch rule shown in photograph. 
Table 9 shows the number of rings per inch by selected inch-groups on the radius combined for the three units.

Table 9. Number of Annual Rings Per Inch on the Radius, and Age Along Radius of Chestnut Stumps

\begin{tabular}{|c|c|c|c|c|c|}
\hline \multirow{2}{*}{ UNIT } & \multicolumn{5}{|c|}{ INCHES FROM CENTER OF STUMP } \\
\hline & $3-4$ & $6-7$ & $8-9$ & $10-11$ & $11-12$ \\
\hline \multicolumn{6}{|l|}{ Spoil } \\
\hline Ave, no. rings ... & 6.1 & 7.7 & $7: 0$ & 7.0 & 8.0 \\
\hline Ave. age* .......... & 26 & 44 & 53 & 59 & 67 \\
\hline No. stumps ....... & 16 & 11 & 5 & 2 & 2 \\
\hline Control & & & & & \\
\hline Ave, no. rings ... & 8.0 & 9.8 & 8.9 & 11.3 & 10.5 \\
\hline Ave. age* ......... & 35 & 64 & 74 & 88 & 101 \\
\hline No. stumps ....... & 20 & 19 & 11 & 3 & 2 \\
\hline
\end{tabular}

*Age at outer inch.

The number of rings per inch on the radius in the inch-groups represented is quite uniform from the 3-4-inch group to the 11-12-inch group. When the trees on the spoils averaged 4 inches in radial growth, and were 26 years old, there were 6.1 growth rings in the last inch. By the time the radial growth had reached 12 inches and at an average age of 67 years there were 8.0 growth rings in the last inch. Therefore, satisfactory diameter growth rate of chestnut is indicated on trees ranging in diameter from 8 inches to as large as 24 inches, and as old as 60 years on the spoils.

A comparison of number of annual rings of chestnut stumps on the spoil with those on the control also is presented in Table 9. The number of annual rings per inch is smaller on the stumps on the spoil than on the control. This indicates a faster diameter growth rate for individual chestnut trees on the spoil. However, this faster growth rate does not necessarily mean a better site quality. Probably the chestnuts that first became established on the spoils had more room for development and were able to develop a larger crown than did those on the control where the density was greater. If this condition existed when the chestnuts became established, the better growth of the trees on the spoil was undoubtedly largely a result of more growing space, and not a better site quality. However, the results do indicate that chestnuts became established on the spoils soon after the spoils were formed, and that they grew in diameter satisfactorily for a 60-year period. 


\section{Root Distribution}

The development of tree roots in the spoil banks was studied in an attcmpt to determinc the suitability of the spoil material as a medium for root growth. Soil pits, dug in studying the rate of soil development on the spoils, indicated a more extensive root development in the spoils than was known to exist in the adjacent undisturbed soils. The site quality of the spoils has been found to be in close agreement with that of undisturbed soil, although the condition of the spoil, particularly when young, is quite different from that of a normal soil. Larger particles comprising the growth medium and a lower nitrogen content are characteristic of the spoil. In view of these differences in the growth medium, where growth is similar, the root development was investigated in a limited manner on the spoil and adjacent control in the hope that an indication for the reason for satisfactory growth of a forest stand on the spoils would be obtained.

The Chestnut Ridge and Johnson Hollow units were chosen for the root study and a soil pit was dug on each spoil and on each control. The pits on each minit were located with reference to uniform and high stand densities, with the pit walls equidistant from, and normal to a radius from, a tree of the same species and same size. The pits were five feet wide and six feet deep on the spoils; the same width and to bedrock on the controls. The wall of each pit was strung in foot squares and the roots charted by size classes. Also, the soil horizons were charted on the controls.

Roots were charted using the following size-class designations.

\section{Diameter of roots (Inches)}

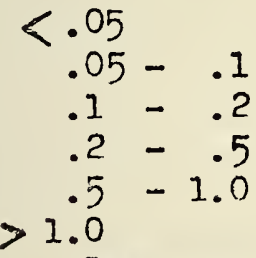

Dead root

\section{Symbol}

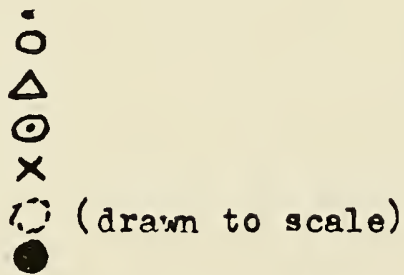

Sandstones were charted to scale and are indicated by cross hatching. The scales on the side of the pits are in feet, and each foot of width is marked on the bottom of the charts.

The root distribution of the Chestnut Ridge Unit is shown for the control in Figure 22 and for the spoil in Figure 23. The pit in the control was two and three-fourths leet deep, the last three-fourth feet 


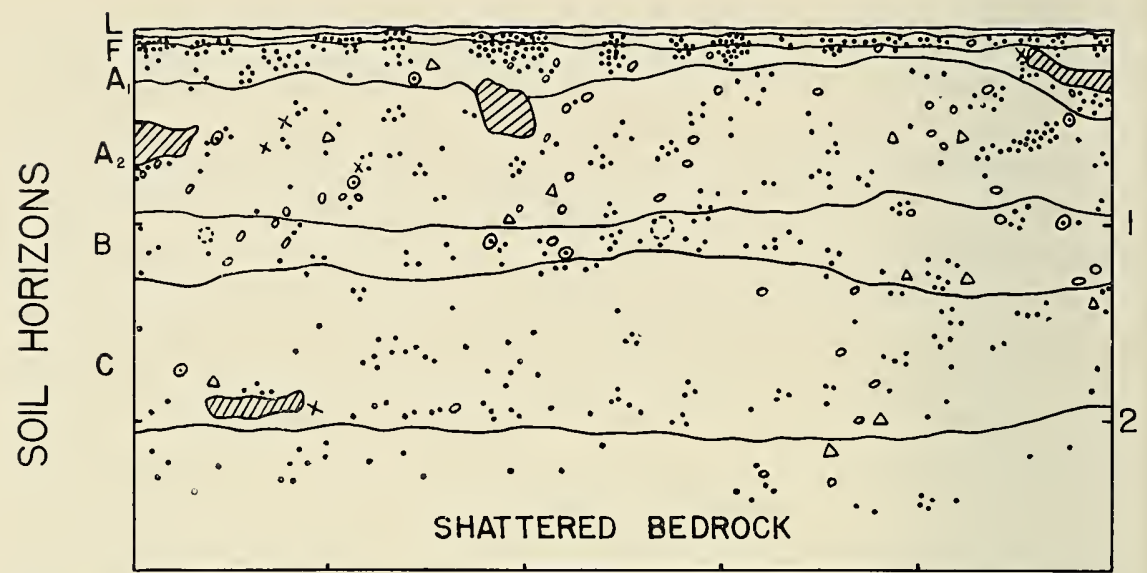

FIGURE 22. ROOT distribution in normal soil (control). Chestnut Ridge Unit.

being in shattered bedrock. The soil in this general vicinity is derived mainly from layers of acid sandstones and shales. Some clay was present. The soil on the hillside would be classified generally as a DeKalb, although at the elevation where the pit was dug it would be in the Gilpin series due to the high amount of shales contprising the bedrock.

The wall of the pit in the spoil was composed mainly of shale particles, although some clay was present. The large amount of shale gave the spoil material a loose texture with good drainage and aeration. In spite of such conditions moisture supply seened to be surprisingly good, even during dry periods. This material appears to be favorable for root development at a greater depth than that of the undisturbed soil on the unit. A layer or zone of clay in the wall of the spoil pit (Figure 23) was less favorable for root development as indicated by the reduction in number of roots there. No attempt was made to show depths of organic layers, although actually a thin F and an L-layer is present on most of the spoil. The number of roots in the pit walls is presented in Table 10 by one-foot deptls.

This table shows numerically the greater depth of root penetration in the spoil material than in the undisturbed soil. The greatest number of roots in any foot is in the upper foot for both control and spoil. Few roots occur below a 2 -foot depth in the control, but on the spoil a considerable number occur to a distance twice that depth and continue, though less abundant, to six feet. More roots occur in the spoil than in the control, these numbers being 923 and 641 , respectively. The greater number in the spoil seems to be a result of the greater depth 


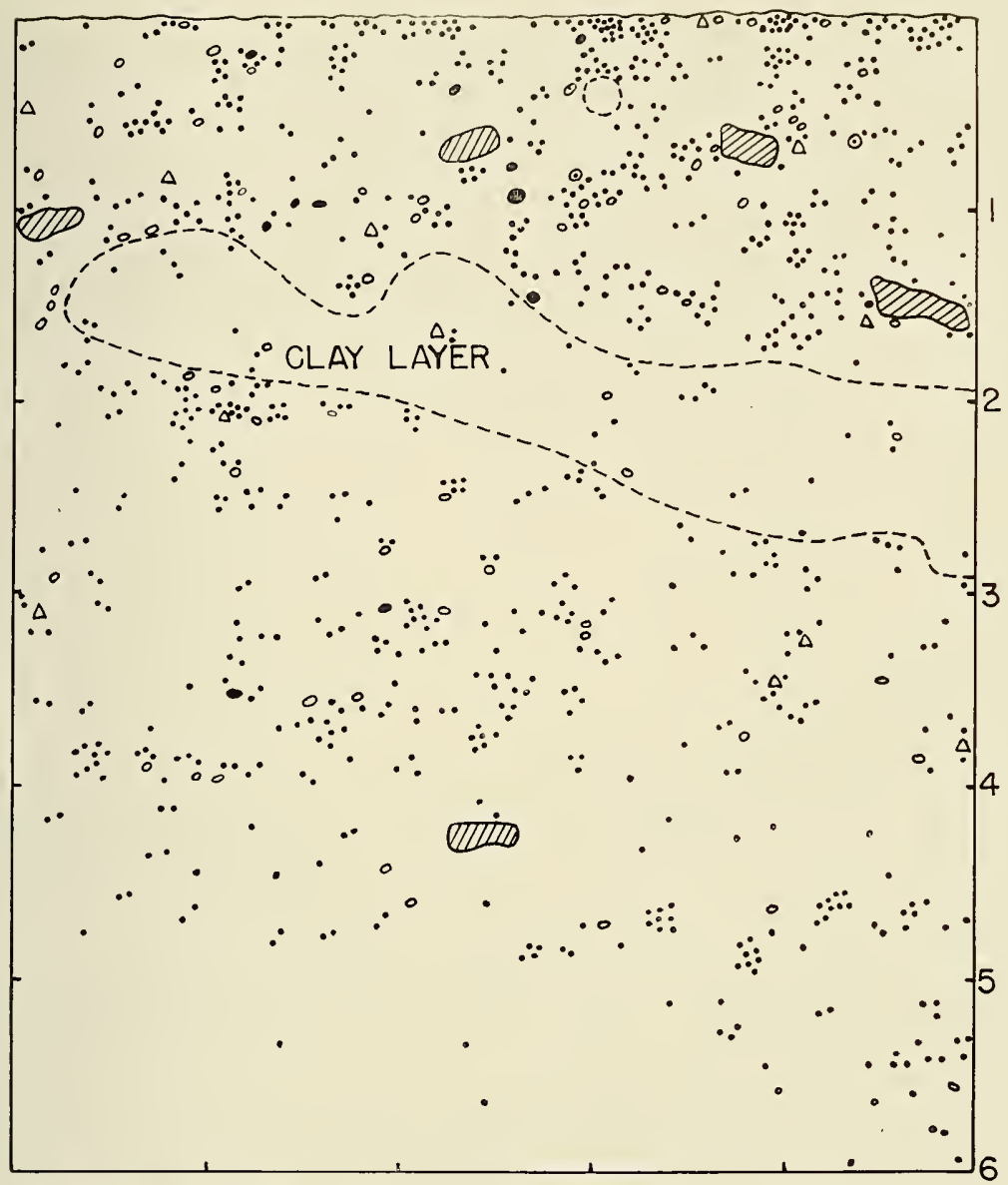

FIGURE 23. ROOT distribution in spoil. Chestnut Ridge Unit.

of root penetration in the spoil, because the control has more roots in the upper two feet than does the spoil, the number being 603 as compared to 529. The upper 2 leet of the control contain 94 per cent of the total number of roots, whereas the upper 2 leet of the spoil contain but 57 per cent.

The distribution of roots of different sizes is very close for the spoil and control. This is shown by percentage values at the bottom of Table 10.

Root distribution in the Johnson Hollow Unit is shown in Figure 24 for the control and in Figure 25 for the spoil. The general soil 
Table 10. Number and Percentage of Rogts by Size-Cilasses and Deptif. Chestnut Ridge Unit

(FIVE-FOOT WIDTH, ROCK-FREE BASIS)

\begin{tabular}{|c|c|c|c|c|c|c|c|c|c|c|}
\hline \multirow{3}{*}{$\begin{array}{l}\text { DEPTH } \\
\text { (FEET) }\end{array}$} & \multicolumn{5}{|c|}{ Control } & \multicolumn{5}{|c|}{ SPoIL } \\
\hline & \multicolumn{3}{|c|}{ DIAMETER Class (IN.) } & \multirow{2}{*}{ TOTAL } & \multirow{2}{*}{$\begin{array}{c}\text { Per } \\
\text { CENT }\end{array}$} & \multicolumn{3}{|c|}{ DIAMETER CLAASS (IN.) } & \multirow{2}{*}{ TOTAL } & \multirow{2}{*}{$\begin{array}{l}\text { Per } \\
\text { CENT }\end{array}$} \\
\hline & $0-.1$ & $.1-.5$ & $>.5$ & & & $0-.1$ & $.1-.5$ & $>.5$ & & \\
\hline $0-1$ & 377 & 48 & 3 & 428 & 67 & 309 & 33 & 1 & 343 & 37 \\
\hline $1-2$ & 150 & 22 & 3 & 175 & 27 & 162 & 18 & & 180 & 20 \\
\hline $2-3 *$ & 35 & 3 & & 38 & 6 & 111 & 9 & & 120 & 13 \\
\hline $3-4$ & & & & & & 153 & 16 & & 169 & 18 \\
\hline $4-5$ & & & & & & 77 & 3 & & 80 & 9 \\
\hline 5.6 & & & & & & 30 & 1 & & 31 & 3 \\
\hline Total & 562 & 73 & 6 & 641 & 100 & 842 & 80 & 1 & 923 & 100 \\
\hline Per cent & 88 & 11 & 1 & 100 & & 91 & 9 & + & 100 & \\
\hline
\end{tabular}

*Actual depth : 2-23/4 feet for control.

type, like that of the Chestmut Ridge Unit, is classified in the DeKall) series, but at the position on the hillside where the pit was dug it would actually be a Wharton soil as clay underlies the $\mathrm{C}$ horizon.

The wall of the spoil pit is composed mainly of shale particles similar to those of the Chestnut Ridge spoil and also gives indication of good drainage and aeration, yet moisture appeared satisfactory. Conditions favorable for root development in the spoil to a depth of six feet are evident in Figure 25, and when the pit was extended to $8 \mathrm{I} / 2$ feet, tree roots were still in evidence, although fewer in number. Most of the roots in the wall of the control pit are in the $A$ and $B$ horizons. A few roots were found in the fire clay near the bottom of the pit. All of these occurred in longitudinal cracks, and may be observed to be so oriented by the location of the groups where two or more roots are directly in line, one beneath the other.

The depth of the roots and their abundance is shown in Table 11 for this unit. The results are quite similar to those obtained for the Chestuut Ridge Unit.

The total number of roots in the spoil wall is greater than in the control wall, (1101 and 787 , respectively). The greatest number of roots per loot of depth is in the upper foot for both pits, although more roots are in the upper foot of the control than the spoil. Most of the roots in the control are in the upper 2 feet, whereas in the spoil they are more evenly distributed throughout. 
Table 11. Number and Percentage of Roots by Si/l-Cilasises ani) DEPTH. JOHNSON HOLLOW UNIT

(FIVE-FOOT WIDTH, ROCK-FREE BASIS)

\begin{tabular}{|c|c|c|c|c|c|c|c|c|c|c|}
\hline \multirow{3}{*}{$\begin{array}{l}\text { DEPTH } \\
\text { (FEET) }\end{array}$} & \multicolumn{5}{|c|}{ CONTROL } & \multicolumn{5}{|c|}{ SPOIL } \\
\hline & \multicolumn{3}{|c|}{ Diameter Class (in.) } & \multirow{2}{*}{ TOTAL } & \multirow{2}{*}{$\begin{array}{l}\text { PER } \\
\text { CENT }\end{array}$} & \multicolumn{3}{|c|}{ Diameter Class (IN.) } & \multirow{2}{*}{ TOTAL } & \multirow{2}{*}{$\begin{array}{l}\text { PER } \\
\text { CENT }\end{array}$} \\
\hline & $0-.1$ & $.1-.5$ & $>.5$ & & & $0-.1$ & $.1-.5$ & $>.5$ & & \\
\hline $0-1$ & 588 & 21 & 9 & 618 & 79 & 385 & 33 & 10 & 428 & 40 \\
\hline $1-2$ & 127 & 5 & 2 & 134 & 17 & 175 & 56 & 4 & 235 & 21 \\
\hline $2-3$ & 20 & & & 20 & 3 & 128 & 24 & 1 & 153 & 13 \\
\hline $3-4$ & 5 & & & 5 & + & 116 & 14 & & 130 & 12 \\
\hline $4-5$ & 10 & & & 10 & 1 & 62 & 29 & & 91 & 8 \\
\hline $5-6$ & & & & & & 56 & 8 & & 64 & 6 \\
\hline Total & 750 & 26 & 11 & 787 & 100 & 922 & 164 & 15 & 1101 & 100 \\
\hline Per cent & 95 & 3 & 2 & 100 & & 84 & 15 & 1 & 100 & \\
\hline
\end{tabular}

The proportion of roots in the different diameter classes varies somewhat between spoil and control, the principal difference being a higher proportion of roots above 0.1 inches in dianeter in the spoil than in the control.

The comparison of root distribution in the spoil banks with that of the controls indicates that a greater number of roots are present in the spoil and that they are more abundant to a greater depth than are those in the natural soil bodies of the two units. This seems to indicate desirable physical properties of the spoil bank for root development. Apparently the broken shales that compose much of the spoil have not been compactect and aeration is satisfactory for root development to the six-foot depth studied. Consequently, the spoil bank is a satisfactory medium for root growth and is satisfactory to a greater depth than the adjacent shallower soil body. Lutz, et al. (10) studied tree root devclopment in natural soils and found that texture of the soil was important in determining root development. Lutz also reported lew roots in compact layers. This was noted in the Chestnut Ridge spoil (Figure 23) where few roots occurred in the clay layer. Many of the works reported in the Review of Literature by Lutz, et al. (10) have pointed out the importance of physical properties of the soil such as texture, acration, moisture, and temperature on the clistribution of tree roots. It is believed, although the study of tree roots in spoil banks is limited and consequently not conclusive, that the spoils have better physical properties for root development to a greater depth than do the shallow undisturbed soils adjacent to these spoil banks. 


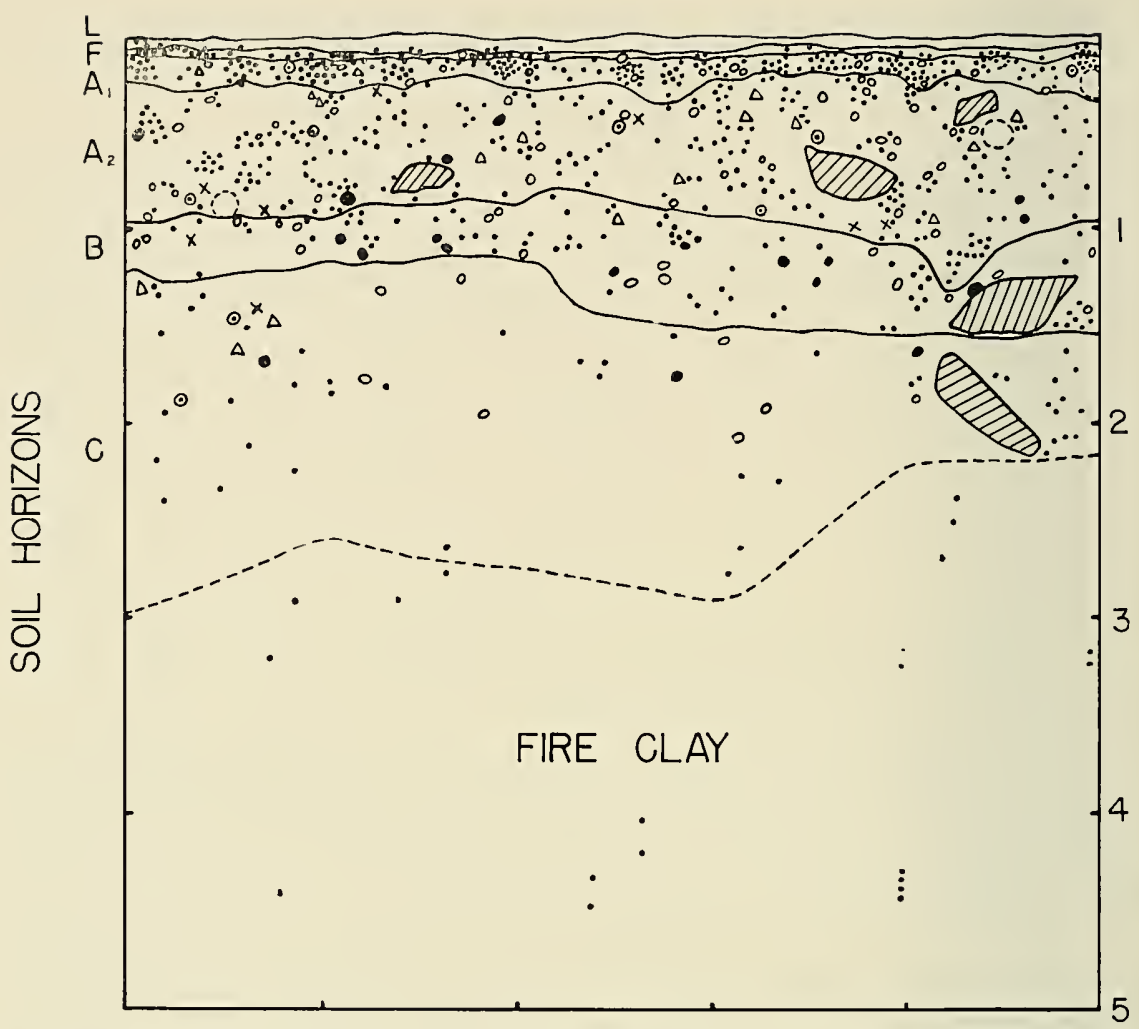

FIGURE 24. ROOT distribution in normal soil (control). Johnson Hollow Unit.

\section{RESULTS OF INVESTIGATION ON GRASSLAND UNITS}

\section{Comparison of Species Abundance On Spoils with Adjacent Controls}

The two grassland units, Peters and Massey, have been described brielly and illustrated under Description of Units. Abundance of species on them was detemined by the inclined point quadrat method, and the data were taken the last two weeks in July, 1950. The results of abundance of species for both units are presented in Table 12.

The relative abundance of species on the Peters Unit is quite similar on the spoil and control, although poverty-grass is higher on the control and redtop and white clover higher on the spoil. A greater difference occurs on the Massey Unit, with Kentucky bluegrass, redtop, 


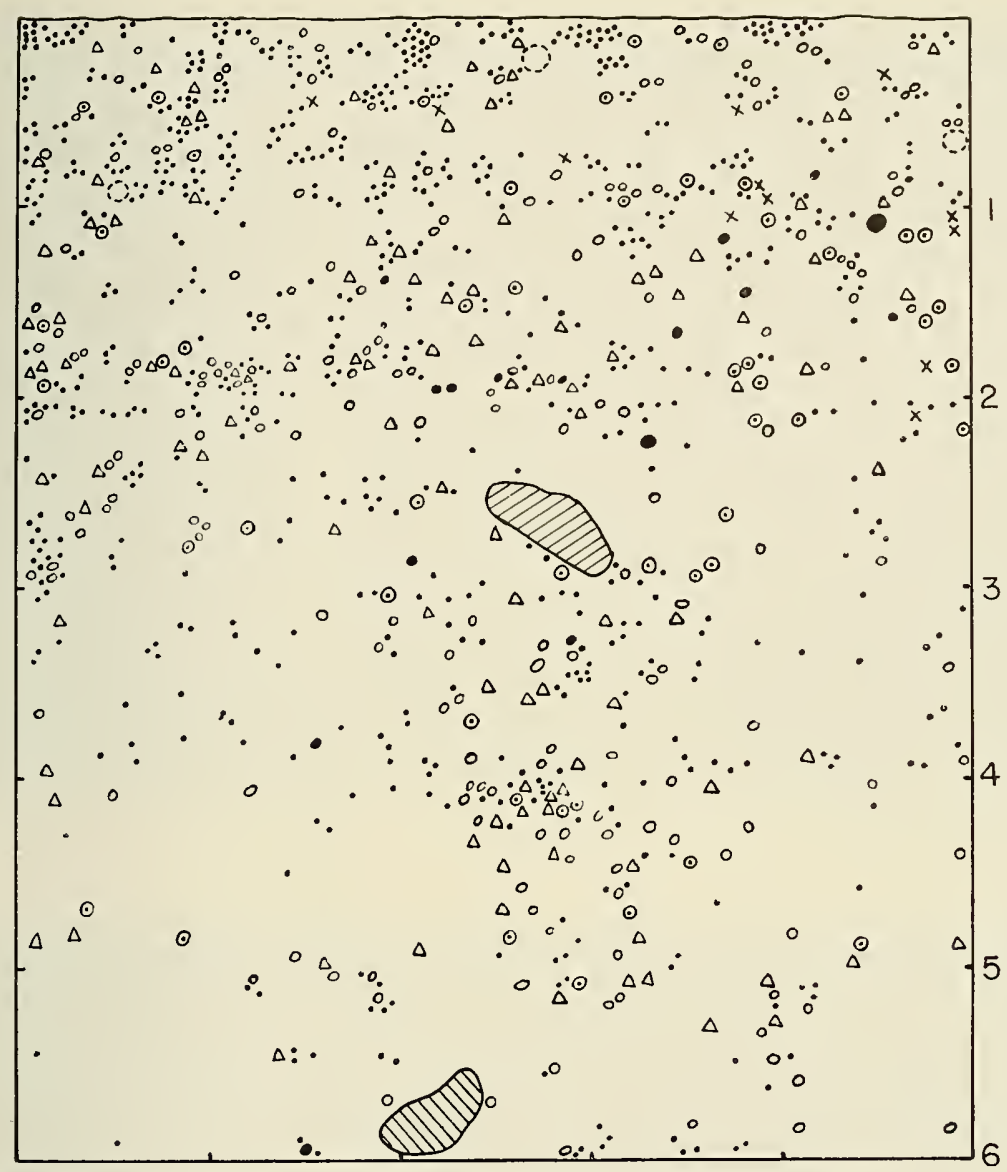

FIGURE 25. ROOT distribution in spoil. Johnson Hollow Unit.

and white clover, as well as species of moss being high on the spoil: and common cinquefoil, poverty-grass and yarrow being higher on the control. Figures 26 and 27 illustrate the difference in species occurring on the Massey control and spoil, respectively. The high abundance of clover on the spoil is particularly noticeable. The differences in species that do exist between spoil and control indicate a slightly better site for pasture grasses on the spoil of the Peters Unit, and a much better site on the spoil of the Massey Unit, than on their respective controls.

The abundance of desirable forage species, which include Kentucky bluegrass, Canada bluegrass, white clover, low hop-clover, redtop, and timothy, is presented in Table 1.3 for both units. 
Table 12. Abundance of Species by Percentage on Grassland Units

\begin{tabular}{|c|c|c|c|c|}
\hline \multirow{2}{*}{ SPECIES } & \multicolumn{2}{|c|}{ Peters Unit } & \multicolumn{2}{|c|}{ MASSEY UNIT } \\
\hline & CONTROL & SPOIL & CONTROL & SPOIL \\
\hline Kentucky bluegrass ............. & 29 & 26 & 5 & 23 \\
\hline Common einquefoil ................. & 15 & 14 & 16 & \\
\hline Poverty-grass & 14 & 2 & 29 & + \\
\hline Redtop & 8 & 23 & 13 & 24 \\
\hline Sheep-sorrel ……........................... & 5 & 3 & 1 & 1 \\
\hline Yarrow & 5 & 6 & 10 & 1 \\
\hline Common eastern dewberry ... & + & 4 & 2 & \\
\hline Easil & 4 & 3 & 1 & 2 \\
\hline Canada bluegrass .................... & 2 & 1 & + & 3 \\
\hline Virginia strawberry & 2 & 1 & + & \\
\hline & 1 & 1 & & \\
\hline $\begin{array}{l}\text { Hairy panic-grass .................... } \\
\text { Wrinkle-leaf goldenrod }\end{array}$ & $\begin{array}{l}1 \\
1\end{array}$ & + & 2 & \\
\hline $\begin{array}{l}\text { Wrinkle-leaf goldenrod } \\
\text { White clover }\end{array}$ & $\begin{array}{l}1 \\
1\end{array}$ & $\begin{array}{l}1 \\
6\end{array}$ & & 23 \\
\hline Southern loosestrife ............... & 1 & fi & 3 & 2.3 \\
\hline Buckhorn plantain ................. & 1 & 1 & 4 & 2 \\
\hline Pasture thistle & 1 & & + & \\
\hline Common dandelion & 1 & + & & \\
\hline Great yellow wood-sorrel .... & 1 & + & + & \\
\hline & + & + & + & \\
\hline $\begin{array}{l}\text { Common mouse-ear } \\
\text { May-apple }\end{array}$ & $\begin{array}{l}+ \\
+\end{array}$ & + & + & \\
\hline Naked flower tick-trefoil .... & + & & 1 & \\
\hline Thyme-leaved speedwell .... & + & & 1 & \\
\hline Blue -eyed grass …................. & + & & & - \\
\hline Crab apple …… & + & & & \\
\hline Timothy ............... & $\begin{array}{l}+ \\
+\end{array}$ & 1 & & \\
\hline $\begin{array}{l}\text { Venus looking glass } \\
\text { Tall agrimony }\end{array}$ & $\begin{array}{l}+ \\
+\end{array}$ & & & \\
\hline Fire-pink & + & + & & \\
\hline Chess & + & + & & \\
\hline Velvet-grass & & 2 & & \\
\hline Violet & & 1 & + & \\
\hline $\begin{array}{l}\text { Selfbeal } \\
\text { Many-flowered nanic-orgss. }\end{array}$ & & + & & \\
\hline $\begin{array}{l}\text { Many-flowered panic-grass } \\
\text { Aster }\end{array}$ & & $\begin{array}{l}+ \\
+\end{array}$ & 1 & + \\
\hline Hairy heuchera & & + & 1 & + \\
\hline Pasture rose & & + & & \\
\hline 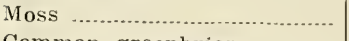 & & + & 3 & 16 \\
\hline Common greenbrier ................. & & $\begin{array}{l}+ \\
+\end{array}$ & & \\
\hline $\begin{array}{l}\text { Slender yellow wood-sorrel } \\
\text { Ground-ivy }\end{array}$ & & $\begin{array}{l}+ \\
+\end{array}$ & & \\
\hline Common speedwell ................ & & + & & \\
\hline $\begin{array}{l}\text { Cleavers } \\
\text { Law hop-clover }\end{array}$ & & + & 3 & \\
\hline Broomsedge & & & 1 & \\
\hline Orange hawkweed ................... & & & 1 & \\
\hline Ox-eye daisy & & & 1 & \\
\hline $\begin{array}{l}\text { Deptford pink } \\
\text { Soutbern loosestrife }\end{array}$ & & & + & \\
\hline $\begin{array}{l}\text { Soutbern loosestrife } \\
\text { American brooklime }\end{array}$ & & & + & 3 \\
\hline Hairy paspalum & & & & 1 \\
\hline Whorled loosestrife ................. & & & & + \\
\hline Common ragweed ..................... & & & & + \\
\hline $\begin{array}{l}\text { Narrowleaf mountain-mint } \\
\text { Tarweed }\end{array}$ & & & & $\begin{array}{l}+ \\
+\end{array}$ \\
\hline Total & 100 & 100 & 100 & 100 \\
\hline
\end{tabular}




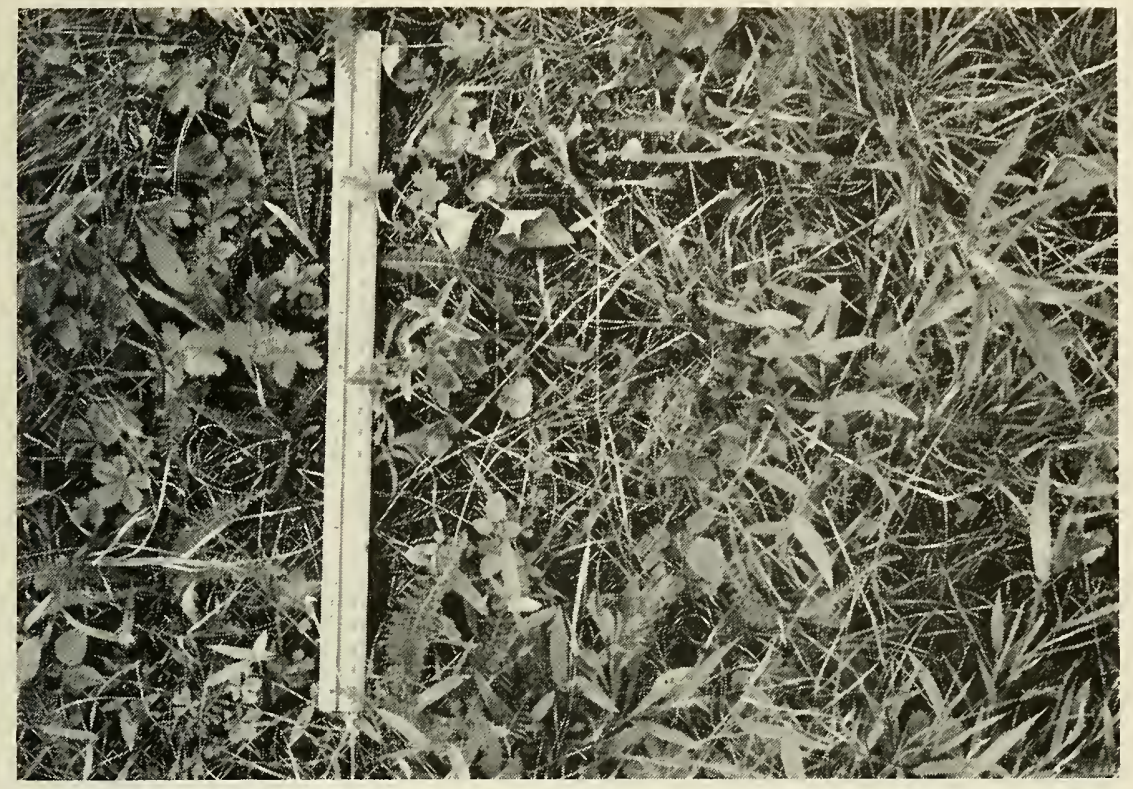

FIGURE 26. VEGETATION on Massey Control. A one-foot scale is in center.

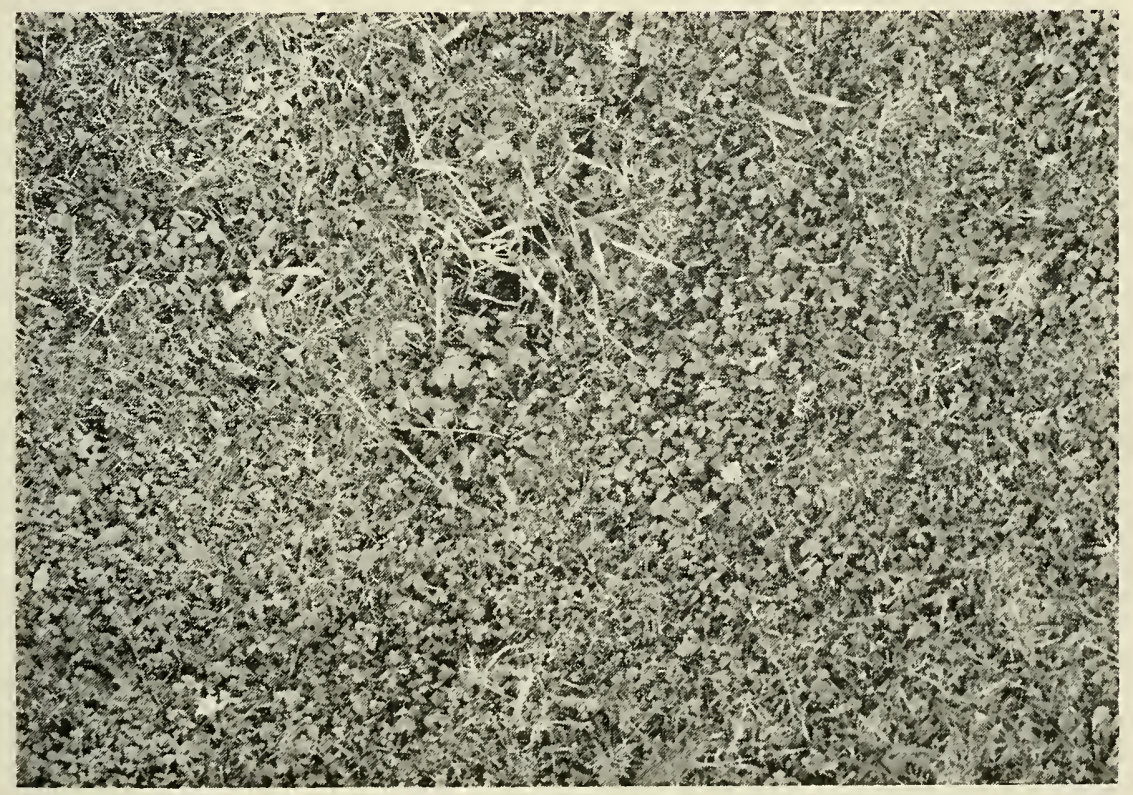

FIGURE 27. VEGETATION on Massey Spoil. Scale same as Figure 26. 
Table 13. Abundance of Desirable Forage Species in Per Cent on the GRASSLAND UNITS

\begin{tabular}{|c|c|c|c|c|}
\hline \multirow{2}{*}{ SPECIES } & \multicolumn{2}{|c|}{ Peters UNit } & \multicolumn{2}{|c|}{ MASSEY UNIT } \\
\hline & Control & SPOIL & Control & SPOIL \\
\hline Kentucky bluegrass & 29 & 26 & 5 & 23 \\
\hline Canada bluegrass & 2 & 1 & + & 3 \\
\hline White clover ....... & 1 & 8 & 3 & 23 \\
\hline Low hop-clover & & & 3 & \\
\hline Redtop & 8 & 23 & 13 & 24 \\
\hline Timothy & + & 1. & & \\
\hline Total abundance \% & 40 & 57 & 24 & 73 \\
\hline
\end{tabular}

The data in this table emphasize the differences between spoil and control noted in Table 12 on abundance of species. The total abundance of desirable forage species is slightly greater on the Peters spoil than on the control, being 57 and 40 per cent, respectively. However, the difference is considerably greater on the Massey Unit, the spoil containing 73 per cent desirable species, whereas the control contains only 24 per cent. These differences indicate better grazing conditions on the spoil than on the control, especially for the Massey Unit.

\section{Comparison of Forage Production On Spoils with Adjacent Controls}

The production of forage material for one season was determined on the Peters and Massey units by the use of one meter square clip quadrats. Three cages were placed on each spoil and on each control in a random manner. A cage in place on the Massey control may be seen in Figure 1.1, and a cage removed so that the crop may be harvested is shown in Figure 28. These cages were needed to protect the forage from cattle that grazed on both mits. The 1951 season crop was harvested by clipping the material within the cages July 14 and again November 9 . The average oven-dry weight of the forage within the clip quadrats is given in Table 14 .

The results for each unit indicate a greater amount of forage produced on the spoil than on the control. The difference in amount between the spoil and control is only 11.9 per cent greater on the spoil of the Peters Unit. However, the spoil of the Massey Unit had 54.5 per cent more forage than the control. 


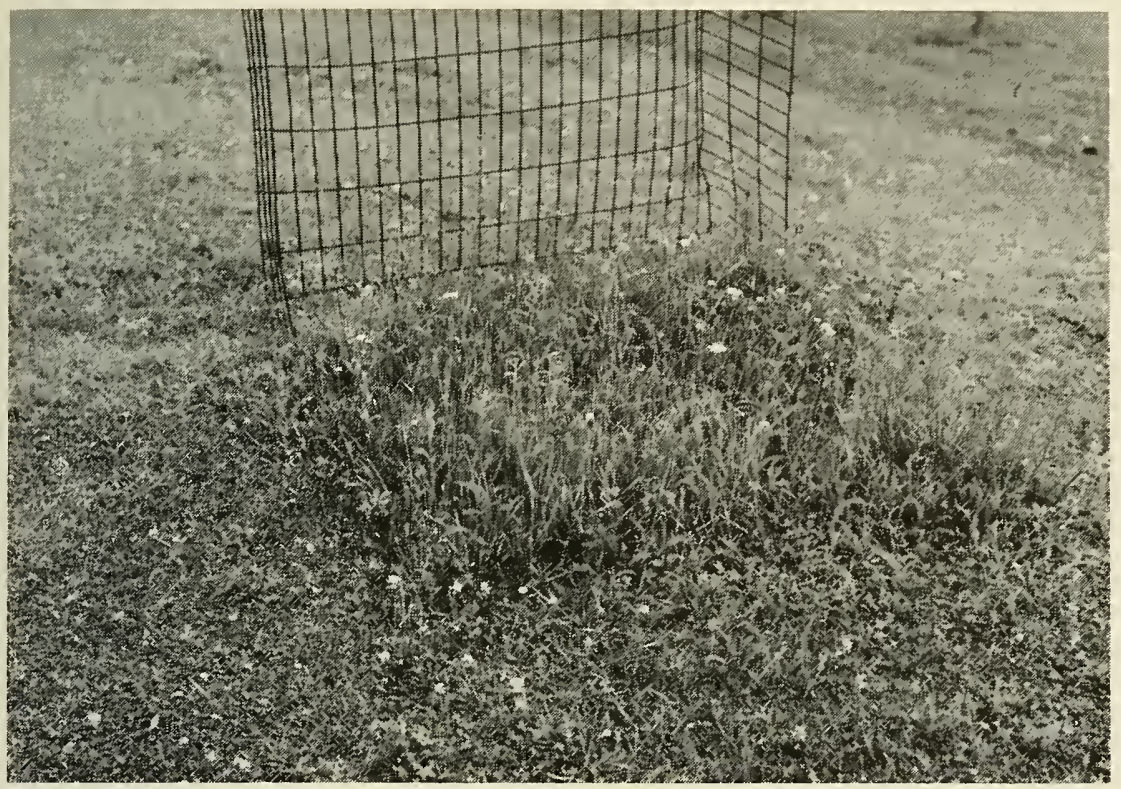

FIGURE 28. CAGE removed so that vegetation may be harvested. Note the heavy grazing around the protected plot.

Table 14. Average forage Production Per Square Meter on the Grassland Units

\begin{tabular}{|c|c|c|c|c|}
\hline UNIT & Phase & $\begin{array}{l}\text { OVEN-DRY } \\
\text { WEIGHT } \\
\text { (GRAMS) }\end{array}$ & $\begin{array}{c}\text { DIFFERENCE } \\
\text { SPOIL-CONTROL }\end{array}$ & $\begin{array}{c}\text { PER CENT } \\
\text { DIFFERENCE } \\
\text { SPOIL-CONTROL }\end{array}$ \\
\hline Peters & $\begin{array}{l}\text { Control } \\
\text { Spoil }\end{array}$ & $\begin{array}{l}715 \\
800\end{array}$ & +85 & +11.9 \\
\hline Massey & $\begin{array}{l}\text { Control } \\
\text { Spoil }\end{array}$ & $\begin{array}{l}451 \\
697\end{array}$ & +246 & +54.5 \\
\hline
\end{tabular}

Although the data are too few to be treated statistically, they do indicate, for both units, that the spoil is capable of producing at least as much forage material as the control. The Massey spoil is actually producing over half again as much as the control, thus indicating that the spoil has a higher site quality from the standpoint of forage production. The results of amount of forage production on spoil and control are in close agreement with the quality of site as determined by the abundance of lorage species.

A comparison of abundance of desirable forage species with forage production by weight is shown in Table 15. The $\mathrm{pH}$ values of each spoil and control also are included. 
Table 15. Comparison of Abunidance of Desirable Forage Species, Forage Production by Weight, and pH on Grassland Units

\begin{tabular}{|c|c|c|c|c|c|c|}
\hline \multirow[b]{2}{*}{ COMPARISON } & \multicolumn{3}{|c|}{ Peters Unit } & \multicolumn{3}{|c|}{ Massey UNIT } \\
\hline & CONTROL & SPOIL & $\begin{array}{c}\% \\
\text { INCREASE } \\
\text { SPOIL- } \\
\text { CONTROL }\end{array}$ & CONTROL & SPOIL & $\begin{array}{l}\% \\
\text { INCREASE } \\
\text { SPOIL- } \\
\text { CONTROL }\end{array}$ \\
\hline $\begin{array}{l}\text { Abundance of desirable } \\
\text { forage species in per cent }\end{array}$ & 40 & 57 & +42.5 & 24 & 73 & +204.2 \\
\hline $\begin{array}{l}\text { Forage production per } \\
\text { square meter in grams ..... } \\
\text { pH }\end{array}$ & $\begin{array}{l}715 \\
5.04\end{array}$ & $\begin{array}{l}800 \\
4.85\end{array}$ & +11.9 & $\begin{array}{l}451 \\
4.99\end{array}$ & $\begin{array}{l}697 \\
5.91\end{array}$ & +54.5 \\
\hline
\end{tabular}

The greater difference in $\mathrm{pH}$ occurs on the Massey Unit, the spoil being nearly one $\mathrm{pH}$ unit higher than the control. However, little difference in $\mathrm{pH}$ exists in the Peters Unit, the $\mathrm{pH}$ of the spoil being slightly less than that of the control.

While the data were being taken on the Massey Unit, both horses and cows were grazing there. They indicated a definite preference for the forage material on the spoil to that of the control to such an extent that the forage material on the spoil was kept low, whereas that on the control was grazed only lightly. This difference in heights of herbaceous plants may be observed in Figures 26 and 27.

\section{CONCLUSIONS}

At the completion of the study, conclusions have been drawn based on the objectives. The objectives, in review, are: (a) to compare the composition and growth of vegetation on old iron-ore spoil banks with that of adjacent undisturbed areas, (b) to determine the ability of a forest stand to develop toward maturity on the old spoils, and (c) to give an idea how well vegetation may be expected to develop on presentday spoil banks formed by stripping for coal.

The abundance of vegetation, both woody and herbaceous, existing on old spoil banks is similar to that of adjacent undisturbed areas.

The site quality of the old iron-ore spoils was found to be quite similar to adjacent undisturbed areas as determined from young forest stands in the Coopers Rock Area. However, these stands all averaged less than 30 years of age. Satisfactory growth of young stands below 30 years of age, such as those examined, does not necessarily indicate that such growth will continue until a reasonable age of harvest has been reached, and this is particularly true on the spoil, an unnatural 
soil body. A more reasonable age might be 60 years for the last growing species on the better sites and 100 years or more for the slower growing species on the poorer sites. Also, these stands developed on the spoils some 50 to 100 years after the banks had been formed. When the spoil banks are first formed they are low in nitrogen. By the time the young stands studied became established, considerable nitrogen must have been added, as one of the spoils 85 to 119 years old and having a low site quality now shows approximately 0.12 per cent nitrogen in the upper six inches for the particles less than $2 \mathrm{~mm}$. in diameter.

Due to the youthfulness of the stands on this unnatural growth medium it is impossible to predict future development. Because of the gradual build-up of nitrogen in the spoils before these stands originated, it is impossible to predict how well such stands would have grown had they become established on newly-formed spoils. So, in order to obtain information on the ability of the spoils to support larger forest trees and their ability to start development on the original young spoils, large isolated trees, stumps, and one small stand of nearly mature trees were investigated.

The recent growth in diameter of individual large trees, and the width of annual growth rings of chestnut stumps on these iron-ore spoils indicate adequate diameter growth. Some of the large trees and chestnut stumps originated as seedlings soon after the spoils were formed and when nitrogen was low, yet growth was satisfactory. Although diameter growth is not a good indicator of site quality, these large trees and stumps do indicate an ability of the spoils to grow trees to an older age than that of the young stands studied more intensively. Also, they indicate the ability of the spoils to support trees established soon after spoil formation.

The stand of large oaks on the one small spoil bank from 72 to 83 years old was nearly as old as the spoil. The growth of these trees indicated that the spoil was fully as good for producing oaks as undisturbed land.

Evidence obtained indicates that the old iron-ore spoil banks are capable of producing hardwood timber. Even trees that became established on the young spoils low in nitrogen have maintained satisfactory growth beyond 60 years of age.

Such good growth of trees on spoils, particularly of the older trees that became established on the young spoils, was surprising to the investigators. The spoil is, in effect, soil and underlying strata turned upside down and mixed, with the topsoil mostly on the bottom; the resulting growth medium is lar different from the original soil, particularly in nitrogen content and texture. 
The reason for such good growth of trees on the spoils is believed to be a result of favorable physical properties of the spoil material. More roots were present, and these extended deeper in the spoil than in undisturbed soils. The shale particles in the spoil caused good drainage and aeration to a depth of at least 6 feet in the spoil, yet moisture seemed plentiful.

Physical properties of soils are known to be of primary importance in promoting tree growth. Because of the apparently desirable physical properties of the spoil, as indicated by root penetration and abundance, the suggestion is made that these may play an important role in the production of the unexpectedly good growth of forest stands on the spoils.

Two grassland spoils produced more forage material and a greater abundance of desirable forage species than did adjacent undisturbed land. Limestone was known to overlay the original iron zone and would be expected to be incorporated in the spoils. One spoil had a $\mathrm{pH}$ approxinuately one unit higher than the adjacent land; the quality and quantity of forage material on this spoil was considerably greater than forage on near-by land. The $\mathrm{pH}$ of the other spoil was slightly lower than the adjacent land, but the amount of forage material was still somewhat greater on the spoil.

The results on one spoil and adjacent land are much as would be expected because increasing the $\mathrm{pH}$, or liming acid land, should improve the forage. On the other spoil and undisturbed land the reverse situation prevails, with the forage better on the spoil where the $\mathrm{pH}$ is slightly lower. From these results it seems that increasing the $\mathrm{pH}$ of the spoil is not the only factor responsible for better growth of forage material on the spoil; apparently some condition within the spoil, other than lime, also is responsible for the increased growth of forage material.

A consideration of all vegetation studied on all of the iron-ore spoils and their respective controls leads to the belief that these spoils are as productive as undisturbed land.

The results obtained from the study of vegetational development on the iron-ore spoil banks should apply, within limits, to the present-day younger coal spoil banks forned by surface stripping. The majority of the coal spoils, even after their first lormation, will support stands of trees whicl grow satisfactorily for at least ten years. The information obtained from the growth of trees on the iron-ore spoils suggests that growth on coal spoils will continue to be satisfactory for many more years if other factors of site are adequate for tree development. 


\section{SUMMARY}

The development of vegetation on iron-ore spoil banks varying in age from 72 to 191 years, and located in northern West Virginia, has been studied to determine the ability of these spoil banks to produce stands of timber or grasses. The results obtained should be of particular importance in helping to determine the future growth of trees and grasses on the present-day coal-stripped spoil banks.

Four forested units and two grassland units were studied. A unit comprises a spoil and its control on adjacent undisturbed land. Within each unit, the vegetation was studied and a comparison made between the spoil and control. The spoils varied in size from 0.5 to 3.8 acres. The forest stands varied in age from 18 to 64 years, with three of the stands being less than 30 years old.

Results of the investigation on forested units indicate:

1. The abundance of woody vegetation above 0.6 inches d.b.h. showed no real difference between spoil and control on three of the units. On one unit, the control had a higher number of stems than the spoil.

2. The basal area did not differ significantly between spoil and control on any of the units.

3. The abundance of reproduction, which includes woody stems less than 0.6 inches, did not differ between spoil and control on three of the units. The abundance was significantly greater on the control of one unit, the same unit which had a greater abundance of woody vegetation on the control.

4. The abundance of ground cover, which includes herbaceous plants and low growing shrubs, was measured by ocular estimation. Little difference occurred between spoil and control in total percentage of ground covered. Similar species were present on spoil and control, and those species most important numerically on the spoil also were higher in abundance on the control.

5. The site quality of spoil and control was compared by units, a commercially important tree species being used. On one unit the control had a higher site quality, but on two units the spoil was higher. On another unit no real difference was found.

6. The growth of large trees that were present in small scattered number on the three spoils supporting stands less than thirty years of age was investigated. Twenty-two trees over 15 inches were studicd. 
The current radial growth rate, as determined by number of rings in the last inch, was found to be rapid in yellowpoplar, red maple, and black cherry. In the species of oak the growth rate was slower but adequate.

7. Chestmut stumps, still well preserved on the three units supporting young lorest stands, were studied by measuring the number of radial annual rings per inch. The largest stump was 24 inches in diameter. Many of the stumps had originated as seedlings soon after the spoils were formed. The ring counts indicated that growth of these formerly existing chestnuts had been satisfactory throughout their life. Diameter growth had been slightly better on the spoil than control.

8. Root development on spoil and control was compared. A greater number of roots was found in the spoil, and roots were especially more abundant at a greater clepth than in the natural soil body.

Results of the investigation on grassland units indicate:

1. Abundance of desirable forage species (bluegrass, clovers, redtop, and timothy) was greater on the spoils than on their respective controls.

2. The production of total forage material, determined by oven-dry weight of a total season's crop, indicated a somewhat higher amount on the spoils than controls. However, the difference in forage production between spoil and control was considerably less than the difference in desirable forage species between spoil and control.

Trees and herbaceous vegetation are growing satisfactorily on old iron-ore spoil banks. Since most of the spoil banks formed by stripping for coal are quite similar to the iron-ore banks studied, it is believed that most of these younger spoils also are capable of supporting stands of timber or forage crops adequate for grazing. 


\section{LITERATURE CITED}

1. Acts of the West Virginia Legislalure Regular Session, 1945. Chap. 85: 345-351. 1945.

2. Baker, F. S., Principles of Siloicullure. New York, NcCraw-Hill Book Co.. Inc., 1950.

3. Braun, E. Lucy, Deciduous Forests of Eastem Norll America. Philadelphia, Blakiston Co., 1950.

4. Chapman, A. G., Rehabilitation of Areas Stripped for Coal. Central States Forest Experiment Station. Technical Paper 108, 1947.

5. Coile, T. S., Relation of Soil Characleristics to Sile Index of Loblolly and Shorlleaf Pines in the Lower Piedmont Region of North Carolina. Dnke Iniversity, School of Forestry Bulletin 13, 1948.

6. Gaiser, Richard N. and Merz, Robert W., "Stand Density as a Factor in Estimating White Oak Site Index." Jour, of For., Vol. 49 (1951), pp. 572-74.

7. Grinsley, G. P., Iron Ores, Salt and Sands/one. West Virginia Geological Survey 4, Morgantown, Acme Publishing Co., 1909.

8. Hennen, Ray V. and Reger, David B., Preston County. West Virginia Geological Survey, Wheeling, Wheeling News Litho. Co., 1914.

9. Lorenz, R. W. and Spaeth, J. N.. "The Growth of Conifers on Prairie Soils." Jour. of For., Vol. 45 (1947), pp. 253-56.

10. Lntz, Harold J., Ely, Joseph B., and Little, Silas, The Influence of Soil Profile Horizons on Root Distribution of Wlite Pine (Pinus strobus L.). Yale University, School of Forestry Bulletin 44, 1937.

11. Moreland, James R.. The Early Chent Mountain Iron Iforks. Morgantown, West Virginia. 1940. (Bound mantsscript, unpublished, in West Virginia University Library.)

12. Oosting, Henry J., The Study of Plant Communities. San Francisco, W. H. Freeman and Co., 1949.

13. Pierre. W. H., and others. West Virginia Pastures: Type of Vegetation, Carrying Capacity, and Soil Properties. W. Va. Agr. Exp. Sta. Bull. 280, 1937.

14. Potter, H. S., Weitzman, S., and Trimble, G. R. Jr., Reforestation of Strip-mined Lands in West Virginia. Northeastern Forest Experiment Station Paper No. 43, 1951.

15. Ralston, Charles W., "Some Factors Related to the Growth of Longleaf Pine in the Atlantic Coastal Plain." Jour. of For., Vol. 49 (1951), pp. 408-12.

16. Rogers, Nelson F., Strip-mined Lands of the IVestem Interior Coal Protince. University of Missouri Mgr. Exp. Sta. Res. Bull. 475, 1951.

17. Society of American Foresters. Forestry Terminology: A Glossary of Technical Terms Used in Forestry. (Com. Rpt.) $93 \mathrm{pp}$. Washington, Society of American Foresters, 1950.

18. Timney, Fred W., Aamodt, O. S., and Ahlgren, Henry L., "Preliminary Report of a Study on Methods Used in Botanical Analyses of Pasture Swards." Jour. Amer. Soc. Agron., Vol. 29 (I937), pp. 835-40.

19. Tyner, E. H. and Snith, R. M., "The Reclamation of the Strip-mined Coal Lands of West Virginia with lorage Species." Soil Sri. Sor. of Amer. Pror.. Vol. 10 (1945), pp. 429-36.

20. Tyner, E. H., Smith, R. M., and Galpin, S. L., "Reclamation of Strip-mined Areas in West Virginia." Jour. Amer. Soc. Agron., Vol. 40 (1948), pp. 313-23.

21. United States Department of Agriculture. Yearbook of Agriculture. Climate and Man. Washington, D. C., 1941 


\section{APPENDIX}

\section{Common and Technical Names of Trees*}

Common Name

Apple, crab

Ash, white

Beech

Birch, black

Blackgum

Cherry, black

Cherry, fire

Chestnut

Cucumbertree

Dogwood, flowering

Elm, American

Elm, slippery

Hawthorn

Hemlock, eastern

Hercules-club

Hickory

Hophornbeam

Locust, black

Maple, red

Maple, sugar

Oak, black

Oak, chestnut

Oak, northern red

Oak, scarlet

Oak, white

Pine, pitch

Sassafras

Serviceberry

Sourwood

Sumac, staghorn

Walnut, black

Witchhazel

Yellowpoplar
Teghnical Name

Pyrus coronaria L.

Fraximus americana L.

Fagus grandifolia Ehrh.

Betula lenta L.

Nyssa syliatica Marsh.

Prumus serotina Ehrh.

Prunus pennsylranica L.

Castanea dentata (Marsh.)

Borkh.

Magnolia acuminata L.

Cornus florida L.

Ulmus americana $\mathrm{L}$.

Ulmus fulva Michx.

Crataegus spp.

Tsuga canadensis (L.) Carr.

Aralia spinosa L.

Carya spp.

Ostrya virginiana (Mill.)

K. Koch

Robinia psendoacacia L.

Acer rubrum L.

Acer saccharum Marsh.

Quercus velutina Lam.

Quercus montana Willd.

Quercus borealis Michx. $\mathrm{f}$.

Quercus coccinea Muenchh.

Quercus alba L.

Pinus rigida Mill.

Sassafras albidum (Nutt.) Nees. Amelanchier arborea (Michx. f.)

Fern.

Oxydendrum arboreum (L.)

$$
\text { (DC.) }
$$

Rhus typhina Torner

Juglans nigra $\mathbf{L}$.

Hammamelis virginiana $\mathrm{L}$.

Liriodendron tulipifera $\mathbf{L}$.

*Technical names used are largely those of W. H. Harlow and E. S. Harrar, Textbook of Dendrology. 3rd Ed. 1950. 


\section{Common and Technical Names of Herbs and Shrubs.}

Common NAME

Agrimony, tall

Aster

Basil

Bellwort, mealy

Blackberry, Allegheny

Blue-eyed grass

Bluegrass, Canada

Bluegrass, Kentucky

Bracken

Brooklime, American

Broomsedge

Carrion-flower

Carrot, wild

Chess

Cinquefoil, common

Cleavers

Clover, white

Cranesbill, wild

Cucumber-root, Indian

Daisy, ox-eye

Dandelion, common

Dewberry, common castern

Dockmackie

Fern, Christmas

Fern, cinnamon

Fern, lowland lady

Fern, maidenhair

Figwort

Fire-pink

Fleabane, daisy

Coldenrod, wrinkle-leal

Grape, summer
Technical Name

Agrimonia gryposepala Wallr. Aster spp.

Satureja tulgaris (L.) Fritsch Uvularia perfoliata L.

Rubus allegheniensis Porter

Sisyrinchium angustifolium

Mill.

Poa compressa L.

Poa pratensis L.

Pteridium aquilinum (L.) Kuhn

var. latiusculum (Desv.)

Underw.

l'eromica americana (Raf.)

Schwein.

Andropogon virginicus L.

Smilax herbacea L.

Daucus Carota L.

Bromus secalinus L.

Potentilla simplex Michx.

Galinu Aparine L.

Trifolium repens $\mathrm{L}$.

Geranium maculatum L.

Medeola virginiana $\mathrm{L}$.

Chrysanthemum Leucanthemum L.

Taraxacum officinale Weber

Rubus flagellavis Willd.

Viburnum acerifolium $\mathbf{L}$.

Polystichum acrostichoides

(Michx.) Schott

Osmunda cinnamomea $\mathbf{L}$.

Athyrium Filix-femina (L.) Roth

var. asplenioides (Michx.)

Farw.

Adiantum pedatumn L.

Scrophularia marilandica $\mathbf{L}$.

Silene virginiaca $\mathbf{L}$.

Erigeron strigosus Muhl.

Solidago rugosa $\mathbf{A i t .}$

Vitis aestizalis Michx. var.

argentifolia (Munson) Fern.

*Technical names used are largely thoso of Gray's Manual of Botany, 8th Ed. 1950. 
Greenbrier, common

Grecubricr, hispid

Ground-ivy

Hawkweed, orange

Hemp, Indian

Hepatica, roundlobed

Heuchera, hairy

Hop-clover, low

Indian-turnip

Knotweed, Virginia

Loosestrife, southern

Loosestrile, whorled

May-apple

Meaclowrue, early

Mountain-mint, narrowleaf

Mousc-ear, common

Nettle, stinging

Nightshade, enchanter's

Panic-grass, Bosc's

Panic-grass, hairy

Panic-grass, many-flowered

Paspalum, hairy

Pink, Deptford

Plantain, buckhorn

Poverty-grass

Poverty-grass, flattened

Ragweed, common

Rattlesmake-root

Redtop

Rose, pasture

Sarsaparilla, wild

Sedge

Selfheal
Smilax rotundifolia L.

Smilax tamnoides L. var. lispida (Muhl.) Fern.

Glechoma hederacea L.

Hieracium aurantiacum $\mathrm{L}$.

Apocynum cannabinum $\mathbf{L}$.

Hepatica americana (DC.) $\mathrm{Ker}$

Heuchera villosa Michx.

Trifolium procumbens $\mathrm{L}$.

Arisaema atrorubens (Ait.)

Blume

Tovara virginiana (L.) Raf.

Lysimachia tonsa Wood

Lysimachia quadrifolia L.

Podophyllum peltatum L.

Thalictrum dioicum L.

Pycnanthemum flexuosum

(Walt.) BSP.

Cerastium vulgatum $\mathrm{L}$.

Urtica dioica $\mathbf{L}$.

Circaea quadrisulcata (Maxim.)

Franch. \& Sav. var. canadensis

(L.) Hara

Panicum Boscii Poir.

Panicum lanuginosum Ell. var. fasciculatum (Torr.) Fern. Panicum polyanthes Schultes Paspalum ciliatifolum Michx. var. Muhlenbergii (Nash) Fern.

Dianthus Armeria L.

Plantago lanceolata L.

Danthonia spicata (L.) Beauv.

Danthonia compressa Aust.

Ambrosia artemisiifolia L. var. elatior (L.) Descourtils

Prenanthes Serpentaria Pursh Agrostis alba L.

Rosa carolina $\mathbf{L}$.

Aralia nudicaulis L.

Carex spp.

Prunella vulgaris $\mathbf{L}$. 
Sheep-sorrel

Snakeroot, black

Speedwell, common

Speedwell, thyme-leaved

Spicebush

Spikenard, false

Squaw-huckleberry

Strawberry, Virginia

Tarweed

Thistle, pasture

Tick-trefoil, naked flower

Timothy

Twisted-stalk, sessile-leaved

Velvet-grass

Venus' looking glass

Violet

Virginia creeper

Woodrush, common

Nood-sorrel, gi eat yellow Wood-sorrel, slender yellow Yarrow
Rumex Acetosella L.

Cimicifuga racemose (L.) Nutt.

Veronica officinalis L.

Veronica serpyllifolia L.

Lindera Benzoin (L.) Blume

Smilacina racemosa (L.) Desf.

Vaccinium stamineum L.

Fragaria virginiana Duchesne

Cuphea petiolata (L.) Koehne

Cirsium pumilum (Nutt.)

Spreng.

Desmodium nudiflorum (L.)

DC.

Phleum pratense $\mathrm{L}$.

Streptopus roseus Michx.

Holcus lanatus L.

Specularia perfoliata (L.) A. DC.

Viola spp.

Parthenocissus quinquefolia (L.)

Planch.

Luzula multiflora (Retz.)

Lejeune

Oxalis grandis Small

Oxalis filipes Snrall

Achillea Millefolium L.

\section{Common and Technical Names of Fungi}

Common Name

Chestnut blight
Technical Name

Endothia parasitica (Murr.)

A. \& A. 
